\title{
Skin development in bony fish with particular emphasis on collagen deposition in the dermis of the zebrafish (Danio rerio)
}

\author{
DOMINIQUE LE GUELLEC ${ }^{1}$, GHISLAINE MORVAN-DUBOIS ${ }^{1}$ and JEAN-YVES SIRE*,2 \\ ${ }^{1}$ Institut de Biologie et Chimie des Protéines (IBCP), Lyon and 'Equipe "Evolution et Développement du Squelette", \\ Université Paris 6- Pierre \& Marie Curie, Paris, France
}

\begin{abstract}
The first part of this article is a review of the current status of knowledge of the fish skin, with particular attention to its development. In the second part we present original results obtained in zebrafish (Danio rerio), with particular emphasis on the deposition and organisation of the dermal collagenous stroma. Using a series of zebrafish specimens aged between 15 hours postfertilization (hpf) and 4.5 years old, we have combined Transmission Electron Microscopy (TEM) observations and in situ hybridisation using type I collagen $\alpha 2$ chain (Col1a2) probe. Collagen fibrils, with a diameter of $22 \mathrm{~nm}$, appear first in an acellular subepidermal space at 24 hpf, are first all oriented in the same direction, and form the primary dermal stroma. Subsequently, three events occur. (1) From 5-7 days pf (dpf) onwards the collagen fibrils self-organise into several lamellae arranged in a plywood-like structure, starting in the upper layers and progressing throughout the entire thickness of the dermis. (2) At 20-26 dpf, fibroblasts of unknown origin progressively invade the acellular collagenous stroma, some of them accumulating below the epidermis. (3) Concomitant with the invasion of fibroblasts, the collagen fibrils increase progressively in diameter to reach $160 \mathrm{~nm}$ towards the end of the fish life. In situ hybridisation experiments reveal that, between 24 and $48 \mathrm{hpf}$, the collagen matrix is produced by the epidermis only. From $72 \mathrm{hpf}$ to 20-26 dpf, both the basal epidermal cells and the dermal cells bordering the deep region of the dermis are involved in the production of collagen. When the fibroblasts invade the plywood-like structure, the epidermal cells progressively cease to synthesise collagen, which from this point is produced only by the fibroblasts. This suggests that the fibroblasts secrete a still unidentified signalling molecule that downregulates collagen production by the epidermis.
\end{abstract}

KEY WORDS: collagen, Col1a2, development, in situ hybridisation, skin, TEM, zebrafish

\section{Introduction}

While the structure, organisation, and composition of fish" skin has attracted the attention of researchers for a long time, information on skin development is very poor. To date, virtually nothing is known of fish skin development and patterning at the molecular level, despite the fact that numerous molecular tools have been available for several years, in particular for the two current fish models, the zebrafish (Danio rerio), and the medaka (Oryzias latipes). This contrasts sharply with the long-lasting interest in skin development in amniotes, and the numerous studies resulting from it: molecular data have particularly accumulated in avian and mammalian models of skin and appendage development, feathers and hairs (see the specific chapters in the present issue).
During the first half of the last century most studies on fish skin have been limited to morphological descriptions of structural diversity, usually in relation to the environment of the fish. From the sixties onwards, the introduction of the electron microscope has induced some authors to investigate the structure of fish skin (mainly epidermis), as well as scale structure and development (Sire, 1987). However, apart from one study dealing with skin development (Nadol et al., 1969), all descriptions concerned features of adult skin.

Previous studies dealing with scale development in a cichlid (Hemichromis bimaculatus) and in the zebrafish (Sire and Géraudie, 1983; Sire et al., 1997; see also the paper dealing with scale development (Sire and Akimenko, 2004) have shown that the developmental processes leading to scale morphogenesis

\footnotetext{
\# In the present paper the word "fish" is used for convenience to refer to actinopterygian fish only and teleosts in particular. Otherwise, fish is a polyphyletic term that includes all living, non-tetrapod vertebrates (lampreys, sharks and rays, actinopterygians, coelacanths and lungfishes) and hagfish.
}

*Address correspondence to: Dr Jean-Yves Sire, CNRS FRE 2696, Université Paris 6- Pierre \& Marie Curie, Case 7077, 7 quai St Bernard, 75251 Paris cedex 05, France. Fax: +33-1-4427-5653. email: sire@ccr.jussieu.fr 
start late during ontogeny (approximately 30 days post-fertilisation (dpf) in $8 \mathrm{~mm}$ SL zebrafish). Several intriguing findings need to be examined further. Indeed, during the larval period that precedes scale formation, the subepidermal collagenous stroma, which constitutes the anlage of the dermis, remains strictly acellular. Fibroblast-like cells (among which are the precursors of the scaleforming cells) next invade the collagenous stroma shortly before the first elements of the scale are deposited. Three questions remain unanswered so far: (1) which cells (epidermal, mesenchymal, or both) are responsible for the deposition of the collagenous stroma in the subepidermal region during the first days of development? (2) How is the collagenous matrix organised into a plywood-like structure during ontogeny? (3) What is the origin of the cells that secondarily invade the well-organised collagenous stroma? In the present paper we first briefly review the current knowledge on fish skin structure and development. In an attempt to answer the two first questions, we then provide original results on zebrafish skin development.

\section{An overview of the current knowledge of fish skin}

\section{Structure and organisation}

The integument is the outer protective barrier that separates the animal from its aquatic environment. The skin encases the body tightly and fulfils several important functions, among which maintaining the body shape, protecting the fish from shocks and various foreign attacks, improving hydrodynamics, and housing sensory functions that are essential for its survival. The structure, organisation and function of the epidermis (which shows a higher structural diversity than the dermis) has interested researchers for a long time, and a large number of descriptions is available (among others: review in Whitear, 1986). The fish skin is composed of three compartments: epidermis, dermis and hypodermis.

The pluristratified epidermis only comprises living cells, in contrast to terrestrial vertebrates which are covered by an outer layer of dead, keratinised cells. Keratinisation is uncommon in fish. It occurs only in specific sites that are subjected to abrasion, such as adhesive organs, lips and pads, and the epidermal surface of some species capable to emerge from the water (Whitear, 1977, 1986). In the adult, the epidermis is composed of several regions, in which the cells have distinctive functions. The superficial stratum is composed of a single cell layer, the outer surface of which is ornamented with microridges. These ornamentations form a pattern that is species-specific (Fishelson, 1984). This ornamentation that retains the mucous substances secreted at the skin surface (Hawkes, 1974; Fishelson, 1984) helps in protecting the fish against bacterial, fungal and parasite attacks. In addition, in providing a larger epidermis surface the microridges probably improve the efficiency of the secretion at the cell surface (Whitear, 1970, 1990). The upper cell layer, through its rich content in microfilaments, probably keratin filaments, also ensures the animal with protection against osmotic shocks, as shown during wound healing (Quilhac and Sire, 1999). These outer epidermal cells are not renewed periodically, but are individually replaced when dead. A variable number of cell layers constitute the intermediate stratum, which involves various specialised cell types: unicellular mucous glands (the mucous goblet cells), which produce antifungal and antibacterial substances included into the mucus; club cells that are supposed to produce alarm substances, e.g., in ostariophysan teleosts (Pfeiffer et al., 1971); sensory cells (review: Whitear, 1986). In some species the epidermis, and probably the mucous cells, produce anti-freeze proteins (Murray et al., 2002). Most cells of this intermediate region remain, however, undifferentiated. They serve as a reservoir to replace dead cells in each of the epidermis regions and they can divide rapidly when necessary, during wound healing for instance (Quilhac and Sire, 1999). The third, deep region of the epidermis is composed of a single cell layer (the basal layer), the main function of which is to keep the epidermis attached to the underlying dermis by means of anchoring structures (hemidesmosomes) attached to the basement membrane. During skin development these basal layer cells fulfil, however, additional functions: (1) they are involved in the production of the early collagenous stroma of the dermis (see the second part of this article), (2) they interact with the underlying mesenchymal cells to initiate the development of the various elements of the dermal skeleton (scales, fin rays and various dermal bones: see review in Sire and Huysseune, 2003), and (3) they are probably involved in the deposition of epidermal substances at the surface of the posterior region of the scales. This epidermal organisation into three strata is invariably the same in all teleost fish species. Variations in thickness and cell composition of the epidermis concern the intermediate region only, and is related to the ecological adaptation of the species. A thin epidermis is the rule in pelagic fish, while benthic fish possess a thick intermediate region able to produce a high quantity of protective substances and to replace dead cells rapidly. In addition, the epidermis is penetrated by nerve fibres. They are either free endings or associated with differentiated epidermal cells of sensory nature, the neuromasts and, most frequently in teleosts, the taste buds (Whitear, 1971a, b).

In the majority of the circa 26,000 teleost species (FishBase, 2002) the well-differentiated dermis contains elasmoid scales. In a few species, such as the gasterosteiforms, it houses dermal plates (bony scutes) and, in some species, there are no hard tissues at all (e.g., the naked catfish). The dermis can be divided into two regions. The superficial region (stratum laxum) is composed of a loose collagenous matrix housing numerous fibroblasts, nerves, some pigment cells, and scales (with a role in protection and hydrodynamics: Burdak, 1979; Sire, 1986). The skin being an accessory respiratory surface, the upper layer of the dermis is most strongly vascularised, particularly around the scales. The deep region (stratum compactum) is characterised by a dense, plywood-like organisation of the collagen matrix, in which some fibrocytes are interspersed. This region is penetrated in some places by vertical bundles of collagen fibrils. In naked species, such as a number of catfishes, the dermis is principally composed of densely packed collagen fibres and is thicker ( 0.6 to $2.0 \mathrm{~mm}$ ) than in scaled species (e.g., less than $0.2 \mathrm{~mm}$ in zebrafish). The thick dermis of naked fishes has been found to be of interest to the leather industry (Junqueira et al., 1983a, b). The primary function of the particular, plywood-like organisation of the collagenous matrix is undoubtedly to strengthen the thin skin to protect the fish against splitting under tensile force. A second interesting function of a plywood-like organisation could be to render the upper region of the fish skin transparent. Indeed, this dermal organisation is analogous to the lamellar structure of the corneal stroma, which is an essential requirement for the high 
transparency of this tissue. In fish skin, by contrast to birds and mammals, most chromatophores, which play a predominant role in behavior, are located below the collagenous stroma. A high transparency of the dermis therefore seems important for the activity of the pigment cells. Initially, the subepidermal region of the fish skin, characterised by a plywood-like organisation of the collagen fibrils, was called "subepidermal collagenous lamella" (Fujii, 1968) and even renamed "basement lamella" (Nadol et al., 1969). This collagenous stroma constitutes the first deposited matrix of the future dermis, and in order to avoid confusion with the basement membrane, we suggest to use "collagenous dermal stroma "for the larval and early juvenile skin and "stratum compactum" instead of "basement lamella" for the adult skin.

The hypodermis (or subcutis) separates the inner face of the dermis from the subjacent muscle cells. In a well-differentiated skin, the hypodermis is composed of a space containing loosely organised collagen, chromatophores (melanophores, iridophores and xantophores), vasculature and a variable number of fat storage (adipose) cells, depending on the species. This hypodermis is bordered, on both sides, by a single layer of fibrocyte-like cells (so far of unknown origin) joined by cell junctions. Whitear and colleagues (1980) have proposed to call such a layer a "dermal endothelium". The deep surface of the hypodermis is interrupted at the level of each myoseptum. A basement membrane separates the epidermis from the dermis and, facing the outer fibrocyte-like layer of the hypodermis, the deep surface of the dermis is lined by a dense zone, resembling a basement membrane (Whitear et al., 1980).

\section{Fish skin collagens}

Several genes encoding collagens have been identified in fish: type I (Morvan-Dubois et al., 2002; Saito et al., 2001), type II (Lele and Krone, 1997), type V/XI (Touhata et al., 2001) and type XVIII (Haftek et al., 2003). The number of published sequences is still limited, but additional sequences are available in databases. The comparison between fish and tetrapod collagen sequences indicates that the main characteristics of collagens were conserved during vertebrate evolution. In skin and intramuscular connective tissue of fish, type I and type $V$ collagens have been identified as major and minor collagen respectively (Kimura et al., 1988; Sato et al., 1989; Yata et al., 2001; Zylberberg et al., 1992; Le Guellec and Zylberberg, 1998).

Compared to tetrapod, fish collagens show two peculiarities: (1) The gene coding for type III collagen, which is known to be associated to type I collagen in the skin of other vertebrate lineages (Keene et al., 1987), has not been found until now in the fish genome. (2) Besides the classical collagen type I $\alpha 1$ and $\alpha 2$ chains assembling to a heterotrimer $(\alpha 1) 2 \alpha_{2}$, fish skin collagen type I has been reported to contain a third chain, $\alpha 3$, leading to an $\alpha 1, \alpha 2, \alpha 3$ heterotrimer (Kimura, 1985; Kimura and Ohno, 1987). This $\alpha 3$ chain is widely distributed in teleosts, but does not exist in sharks and lampreys (Kimura et al., 1987) and has not been found in some teleost species such as the fugu (Takifugurubripes) (Nagai et al., 2002). The genes coding for the $\alpha 1, \alpha 2$ and $\alpha 3$ chains of collagen type I have been cloned and sequenced in fish (trout and zebrafish) (Saito et al., 2001; Morvan-Dubois et al., $2002,2003)$. The analysis of the molecular evolution of these various chains indicates that the $\alpha 3$ chain is derived from a duplication of the $\alpha 1$ gene that has occurred probably in the actinopterygian lineage (Kimura and Ohno, 1987; Morvan et al., 2003). The collagen type III $\alpha 1$ chain has probably been lost in this lineage. However, the structural significance of the collagen type I $\alpha 3$ chain in teleost skin remains to be clarified.

\section{Fish skin development: a virgin field of research}

Cell fate studies in the zebrafish have shown that the epidermis differentiates from an epidermogenic cell population of the embryonic ectoderm, along with neurogenic cell populations giving rise to the central nervous system and the neural crest (Schmitz et al., 1993). The dermis derives from the paraxial mesoderm (dermatome region), except for the head region, where it derives from the (ecto)mesenchyme of neural crest origin. In embryos (at $90 \%$ epiboly) the epidermis consists of a single layer of more or less polarized cells covered by an external,"enveloping" layer, the periderm. The epidermal cells fuse at the midline approximately at 14-somite stage (Schmitz et al., 1993).

Some questions remain unsolved so far. How is the transition achieved, in the early stages of skin development, from two cell layers towards the typical epidermis composed of three strata? What is the fate of the periderm? Does it disappear as in birds and mammals during the last period of development? Does the intermediate region, which seems to appear secondarily and which possesses undifferentiated cells, contain stem cells?

The skin in embryos and young larvae is very thin (less than $10 \mu \mathrm{m}$ thick). In consequence, only transmission electron microscopical studies can provide an accurate morphological description of the early development of the epidermis and dermis. Working on the skin of embryos and larvae of Fundulus heteroclitus, Nadol and colleagues (1969) have described the deposition of the collagenous stroma of the dermis as an "adepithelial basement lamella". The first deposited collagen fibrils seem to be inserted into the lamina densa of the basement membrane, and offer a mean by which the dermis firmly supports and binds the epidermis. These authors suggest that the fibroblasts, which are located only below the collagenous stroma in Fundulus larvae, synthesize the collagen matrix. This interpretation does not fit with the observation that the deeper surface of the collagenous stroma is very poor in fibroblasts at the onset of the collagen deposition in the subepidermal space.

\section{Skin development in zebrafish (Danio rerio) with particular attention to collagen deposition in the dermis}

In the second part of this paper, we will focus on (1) the formation of the collagenous stroma, its progressive organisation and its remodelling through ontogeny, and (2) the cells responsible for the synthesis of this extracellular matrix. To achieve these aims we have used a growth series of zebrafish, and we have studied skin development using a combination of conventional transmission electron microscopy (TEM) and in situ hybridisation, both at the light and TEM level, using a probe of collagen type I $\alpha 2$ chain (Morvan-Dubois et al., 2002).

\section{Results}

The following description of skin development in the zebrafish is based on transverse sections of the caudal peduncle, at the level of the anal fin region. We are aware that the features of the zebrafish skin morphology in embryos, larvae, juveniles and 

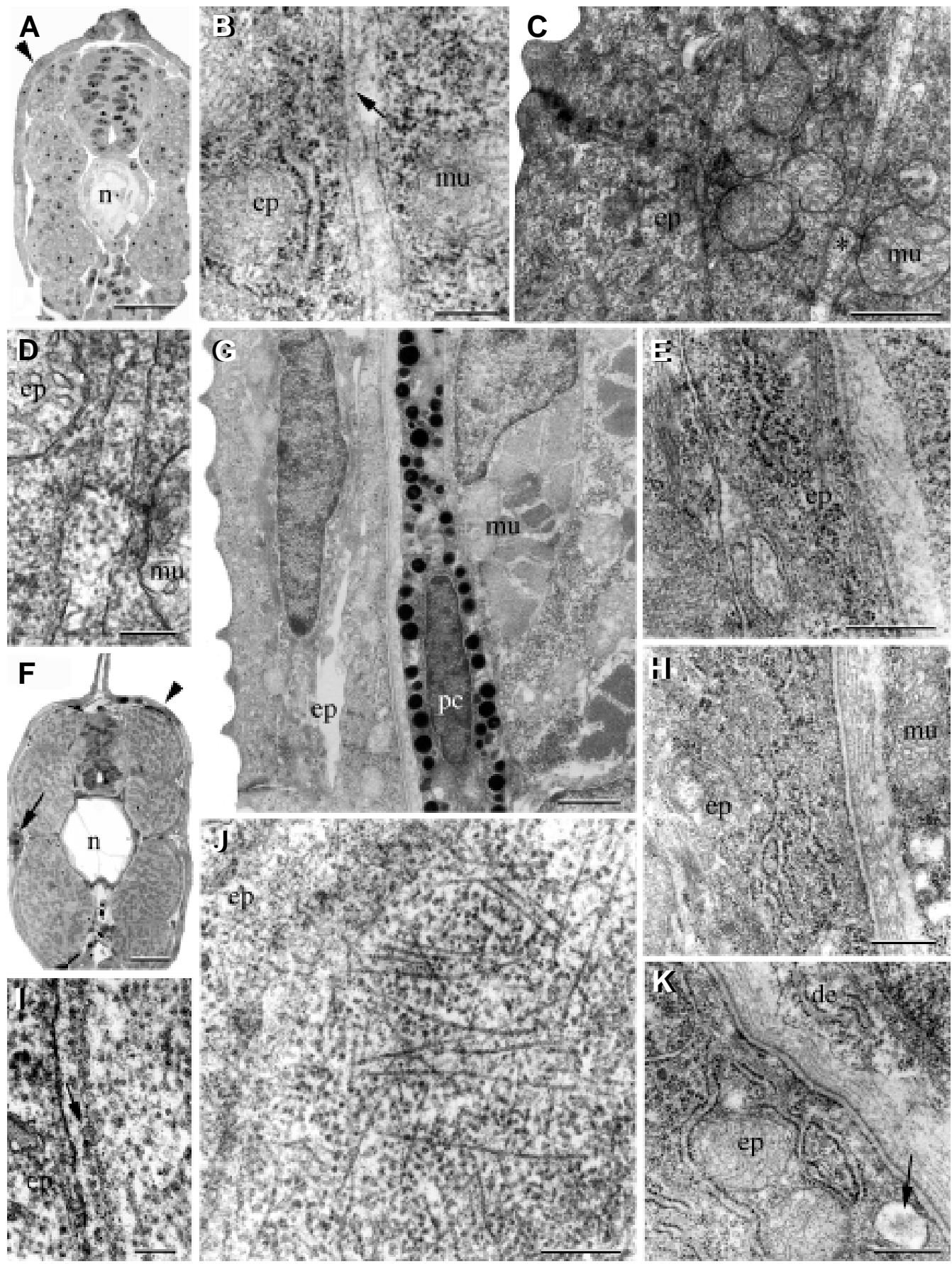
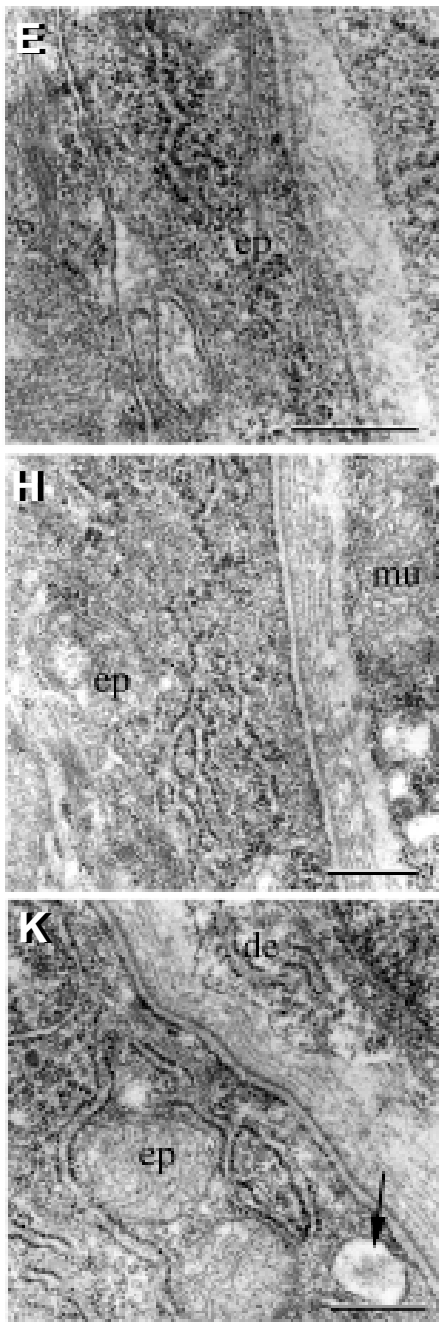

Figs. 1-4. Transmission electron micrographs (TEM) of the zebrafish skin in a growth series (from $24 \mathrm{hpf}$ embryos to a 4.5-years old specimen).

The sections are perpendicular to the antero-posterior axis, except for figures $1 \mathrm{~J}, 3 E$ and $3 K$, which are from sections made at an angle of $45^{\circ}$ to this axis. Some light micrographs of transverse sections through the anal fin region are presented at various stages to follow the changes occurring in this region of the body during ontogeny. In all TEM micrographs, the body surface is on the left.

Fig. 1. First deposition of collagen fibrils. (A-D) $24 \mathrm{hpf}$, (E) $32 \mathrm{hpf}$, (F-J) 48 hpf embryos and (K) 58 hpf larvae. (A) The skin is thin and the subepidermal space and connective tissue cells are hardly visible at this low level of magnification; the arrowhead indicates the region detailed in $(B)$. The muscle cells are differentiating, while the myosepta are not well defined yet. The notochord is not yet completed. The large spaces visible between the skin and the muscles are artefactual. (B) Detail of the subepidermal space between the epidermis and the muscle cells. Cisternae of the rough endoplasmic reticulum (RER) are visible in the basal epidermal cells. A distinct but interrupted basement membrane (arrow) lines the epidermal cell membrane, while it is less visible at the surface of the muscle cells. Some extracellular material is located in the subepidermal. (C) The same skin organisation as in $(B)$ is observed in the anterior body region, but the material filling the extracellular space appears more granular and electron-dense. The basement membrane is hardly distinguishable. The epidermis is composed of two cell layers, the cells of the upper layer being ornamented with short microridges. (D) Detail (* in Fig. C) of the subepidermal space which is filled with a thin, granular matrix. 32 hpf. (E) The subepidermal space has enlarged a little and contains unorganised fibrillar material. The basement membrane is present but not yet entirely differentiated. 48 hpf. (F) The artefactual spaces have disappeared, indicating a better anchorage of the epidermis to the collagenous stroma. Some connective tissue cells are seen at the muscle surface, and in particular, the first pigment cells are observed in the dorsal region (arrowhead). This region is detailed in (G). The muscle cells are now differentiated and the myotoma start to separate them. The horizontal septum is well defined and some neuromasts are differentiating in the skin opposite (arrow). (G) Skin of the dorsal region of the same specimen (arrowhead in Fig. F). The epidermis is two layers thick and the basement membrane is well differentiated. A melanocyte with dark melanin granules is located close to a muscle cell. (H) The cytoplasm of the basal layer of the epidermis contains a number of polysomes, RER and microfilaments. A fibrillar matrix composed of thin collagen fibrils parallel to one another and to the section plane has been deposited in the subepidermal space, constituting the so-called primary dermal stroma. (I) Anterior region of another specimen showing the majority of fibrils running parallel to the antero-posterior axis. An arrow points to the granular layer inside the lamina lucida of the basement membrane. (J) Oblique section showing the 2D organisation of the collagen fibrils in the extracellular space. 58 hpf. (K) Note the presence of mitochondria and cisternae of the rough endoplasmic reticulum in the cytoplasm of the basal epidermal cell layer. A large secretory granule is seen merging with the cell membrane facing the collagenous stroma (arrow). Abbreviations: ep, epidermis; mu, muscle cells; $n$, notochord; pc, pigment cell. Scale bars: A, F, $50 \mu$ m; B, C,J, $250 \mathrm{~nm}$; $D, G, 1 \mu \mathrm{m} ; E, H, K, 500 \mu \mathrm{m} ; \mathrm{I}, 100 \mathrm{~nm}$. 
Fig. 2. Thickening of the primary dermal stroma. (A-C) $72 \mathrm{hpf},(D, E) 96 \mathrm{hpf}$ and $(F, G) 120$ hpf larvae (5 days pf), (H) 7 dpf larvae. (A) The epidermis is underlined by a thin subepidermal space that separates the skin from the muscle cell surface. The arrowhead points to the region detailed in Fig. B. (B) Detail of the skin region (arrowhead in Fig. A). The subepidermal space between the epidermis and the muscle cells is enlarged. Abasementmembrane (arrow) is present below the surface of the basal epidermal cell. The collagenous stroma is denser than in the previous stage. It is composed of thin fibrils arranged mostly parallel to the section plane with, however, some fibrils sectioned at a right angle with the former. (C) In the anterior region, most of the collagenous stroma is composed of fibrils transversely sectioned, i.e. parallel to the antero-posterioraxis of the fish, and irregularly spaced. 96 hpf. (D) In 96 hpf larvae the epidermis is still composed of two cell layers with the basal layer showing a well-differentiated cytoplasm. Some elongated fibroblast-like cells are located at the muscle surface below the collagenous stroma. (E) Detail $*^{*}$ in Fig. D) of the subepidermalspace showing a collagenous stroma mainly composed of thin parallel, more regularly spaced fibrils. 120 hpf (5 days pf). (F) The fibroblast-like cells that line the deep surface of the collagenous stroma show a well-differentiated cytoplasm with numerous RER cisternae and mitochondria. These cells are linked to each other by desmosomes (arrow). (G) Detail of the basement membrane and of the collagenous stroma. Note the
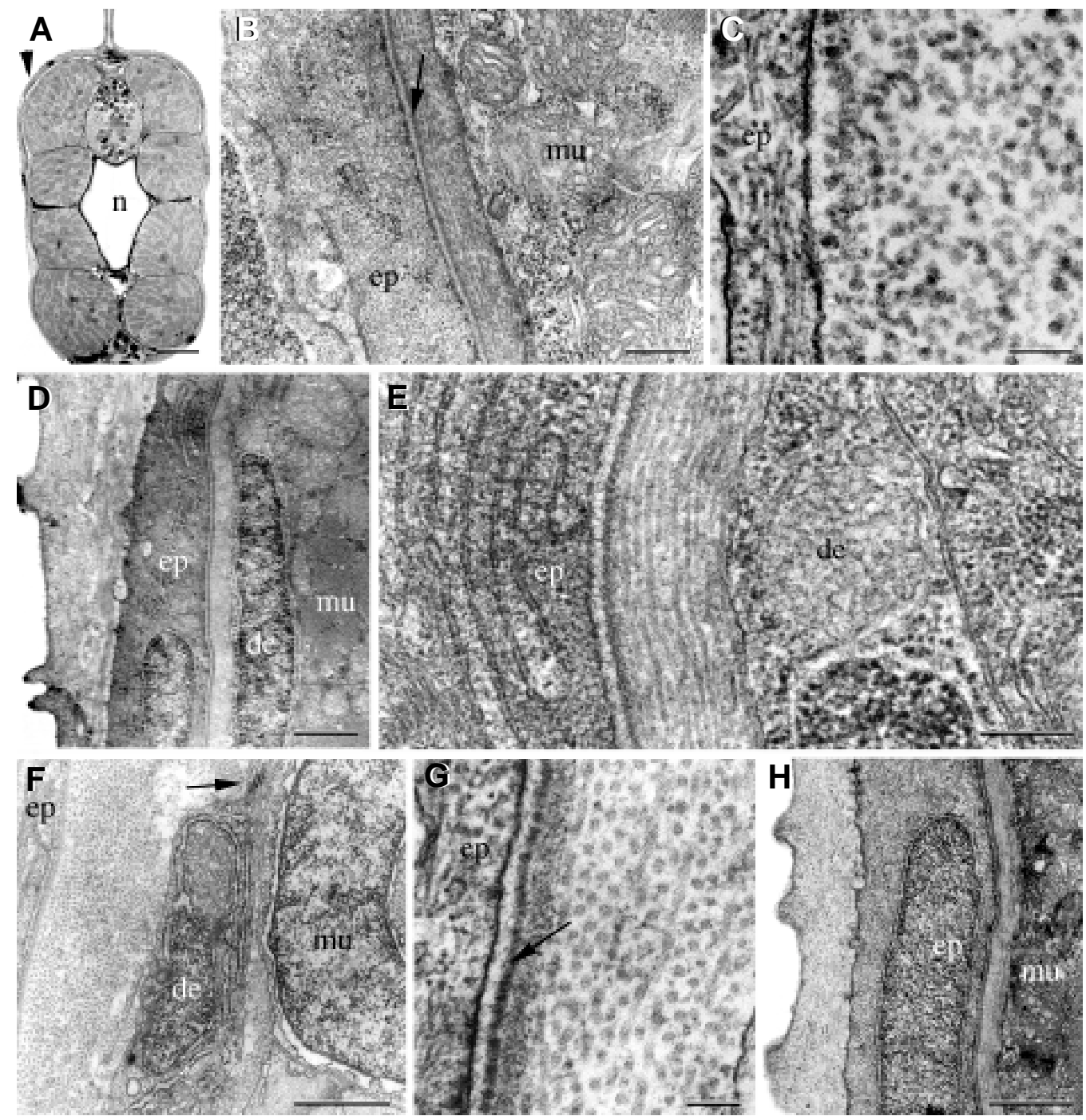

presence of a layer of dense granules inside the lamina lucida (arrow). (H) 7 dpf. The epidermis is still two cell layers thick. In this region the deep surface of the collagenous stroma is in direct contact with the muscle cells. Abbreviations: de, dermal endothelial cells; ep, epidermis; mu, muscle cells; $n$, notochord. Scale bars: $A, 50 \mu \mathrm{m} ; B, E, 250 \mathrm{~nm} ; C, G, 100 \mathrm{~nm} ; D, F, H, 1 \mu \mathrm{m}$.

adults can differ in the other regions of the body, both temporally (variations due to skin differentiation progressing from anterior to posterior) and spatially (variations due to regional differences in skin composition in embryos and young larvae, e.g. in the head, the general cavity, the yolk sac, and the developing fins).

\section{Organisation and remodelling of the collagenous matrix throughout ontogeny}

\section{First collagen fibril deposition in late embryos}

The skin (epidermis, dermis and hypodermis) starts to differentiate at $24 \mathrm{hpf}$. Before this stage, i.e. from $15 \mathrm{hpf}$, the body of the embryos is surrounded by two layers of epithelial cells covering some undifferentiated mesenchymal cells. The limit between the two tissues is sometimes difficult to recognize as there is no clear boundary between the epithelial and mesenchymal cells (not shown). In 24 hpf embryos, the epithelium is about $4 \mu \mathrm{m}$-thick and composed of two cell layers hardly distinguishable at the light microscopic level (Fig. 1A): a superficial layer, the so-called enveloping layer, and a basal layer (Fig. 1C). Numerous desmosomes connect the epithelial cells within each layer and between the two layers. The epithelial cells are poor in organelles, and only a few ribosomes, cisternae of the rough endoplasmic reticulum (RER) and mitochondria are visible. A thin, $0.2 \mu \mathrm{m}$-thick, subepidermal space, which contains a loose collagen matrix, is observed immediately below the basal epidermal layer (Fig. $1 \mathrm{~B}, \mathrm{C}$ ). The organisation of the collagen matrix is irregular, depending on the regions of the body (compare Fig. $1 \mathrm{~B}, \mathrm{C}$ ). In some areas, the collagen matrix is not distinguishable, while in other places, it fills a subepidermal space not thicker than $1 \mu \mathrm{m}$. An often fragmented and sometimes hardly visible basement membrane is observed along the epithelial surface facing the subepidermal region. The collagen fibrils are either cross sectioned or parallel to the section plane depending, again, on the region of the body (Fig. 1 B,D). This indicates that, in a particular region all collagen fibrils are oriented parallel to each other and to the epithelial surface (Fig. 1C). The fibril diameter is $22 \mathrm{~nm}$, with irregular space in 
Fig. 3. Formation of the plywoodlike arrangement. (A-F) $10 \mathrm{dpf},(\mathrm{G}-\mathrm{H})$ $15 \mathrm{dpf}$ and (I-K) $20 \mathrm{dpf}$ larvae. (A) The skin is not really thicker than in the previous stages. Some mucous cells are visible within the epidermis (arrows). (B) Detail of the skin region (arrowhead in Fig. A). The epidermis is still two cell layers thick. The cells of the basal layer facing the collagenous stroma are enriched with microfilaments. The collagenous stroma is dense and composed of thin fibrils arranged either parallel to the section plane or at a right angles. The deep surface of the collagenous stroma is lined by elongated fibroblast-like cells covering the muscle cells. (C) In another region of the same section, the deep surface of the collagenous stroma is directly in contact with the muscle cells. (D) Detail of the same region showing the arrangement of the collagen fibrils into layers with alternate orientation. In the deep region of the collagenous stroma the fibrils have not changed their orientation. (E) Oblique section showing the orthogonal organisation of the fibril network. (F) Same section in the region communicating with the horizontal septum * $^{*}$ in A). The upper region shows an orthogonal organisation of the collagenous stroma, whereas the deep region is still unorganised, with collagen fibrils filling the extracellular space of the septum. Note the well-developed network of RER of the fibroblast-like cells lining the deep surface of the collagenous stroma. $15 \mathrm{dpf}$. (G) The cytoplasm of the epidermal basal layer
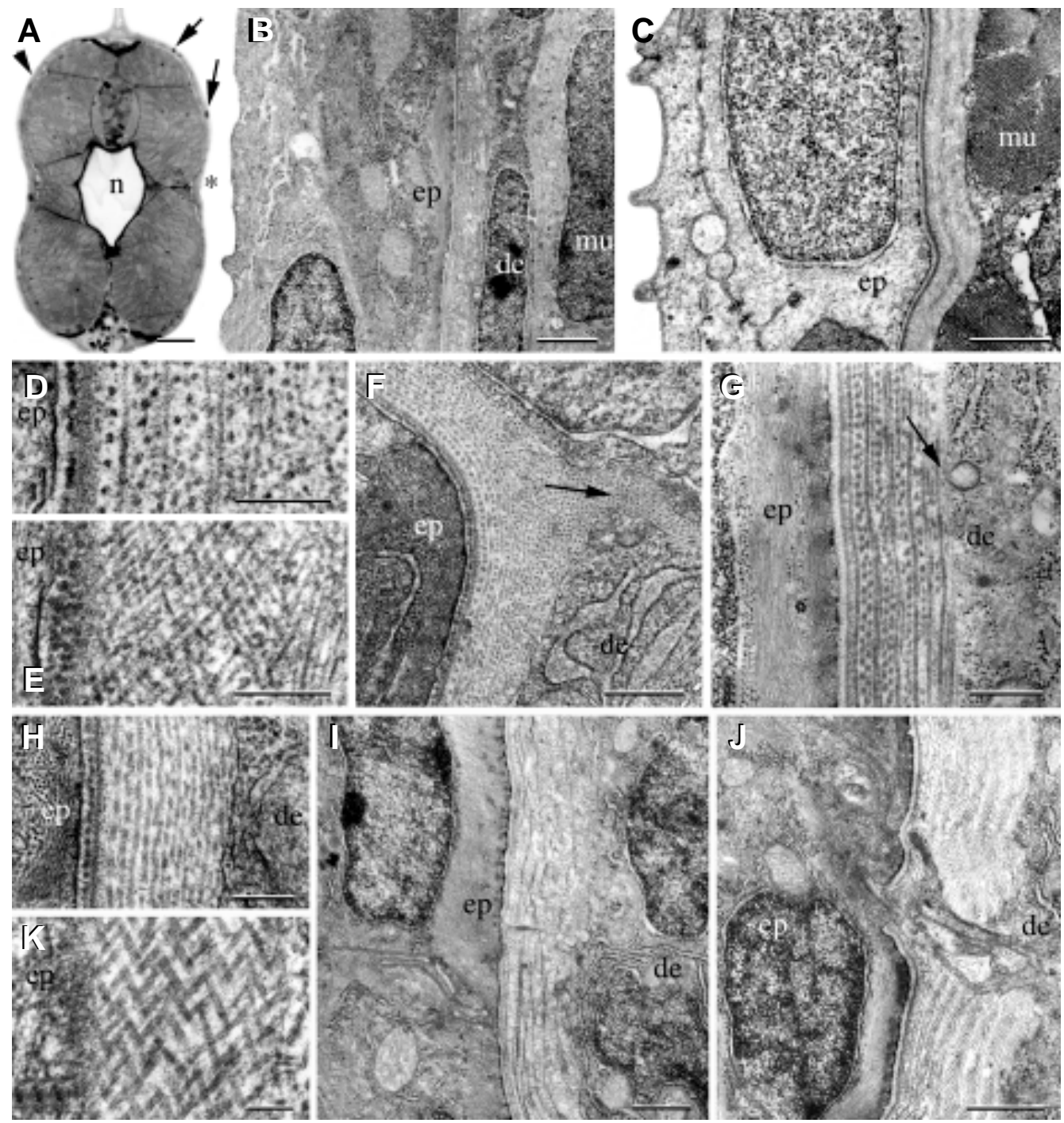

cells facing the collagenous network is rich in bundles of microfilaments that anchor by means of hemidesmosomes on the cell membrane. The fibroblast-like cells lining the collagenous stroma show a well-differentiated cytoplasm. The collagenous stroma is still composed of thin fibrils, but it is well-organised into a plywood-like structure. (H) More anteriorly the collagenous stroma is still mainly composed of fibrils parallel to each other and to the section plane. $20 \mathrm{dpf}$. (I) The cytoplasm of the epidermal basal layer cells shows numerous bundles of microfilaments and the cell membrane is lined by many hemidesmosomes. Some organelles are, however, still observed in the other regions of the cytoplasm. The fibroblast-like cells at the deep surface of the collagen network have enlarged and their cytoplasm is well-differentiated with numerous RER cisternae, mitochondria and secretory granules. (J) In some regions, cytoplasmic prolongations from the fibroblast-like cells are seen to cross the collagenous stroma and to reach the basement membrane. There is a clear correlation between the presence of these cytoplasmic processes and the deposition of vertical bundles of collagen fibrils. (K) This oblique section shows the orthogonal organisation and the relationship of the collagen fibrils within the entire thickness of the collagenous stroma. Abbreviations: de, dermal endothelial cells; ep, epidermis; mu, muscle cells; $n$, notochord. Scale bars. A, $50 \mu m$; $B, C, I, J$, $1 \mu \mathrm{m} ; \mathrm{D}, E, \mathrm{H}, 250 \mathrm{~nm} ; F, G, 500 \mathrm{~nm} ; K, 100 \mathrm{~nm}$.

between (Fig. 1D). The subepidermal space is often artefactually enlarged during the fixation process, a feature indicating a weak connection between the epidermis and the surface of the differentiating muscle cells.

A few hours later, at $32 \mathrm{hpf}$, the subepidermal space is enlarged and a well-defined, uninterrupted, basement membrane is formed. The collagen fibrils of the subepidermal space are more regularly organised and form the initium of the collagenous stroma of the dermis (Fig. 1E), that we propose to name the primary dermal stroma.

At hatching (48 hpf), the skin of the embryo is still composed of two epithelial cell layers (Fig. $1 F, G$ ), and of a primary dermal stroma that is continuous. This primary dermal stroma is thicker than before $(0.5 \mu \mathrm{m})$, and its thickness however still varies depending on the body regions. In some areas, melanophores are located in the deep dermis (Fig. 1G). The basal epidermal cells show a welldeveloped network of RER indicating a more intense activity in protein synthesis compared to the previous stage. The collagen fibrils have the same orientation, organisation and diameter (22 $\mathrm{nm}$ ) as described at 24 and $32 \mathrm{hpf}$. In an oblique section, both longitudinally and cross-sectioned collagen fibrils are observed, but no particular organisation can be distinguished (Fig. 1J). The lamina lucida and lamina densa of the basement membrane are 
differentiated and separate the basal epidermal cell layer from the upper region of the primary dermal stroma. Accumulations of granular material ( $22 \mathrm{~nm}$ in diameter), the so-called adepidermal granules (Nadol et al., 1969), are present in the lamina lucida of the basement membrane (Fig. 1I). Opposite the epidermal cell surface, the muscle cells are well-differentiated, and no fibroblast-like cells are observed lining their surface, the primary dermal stroma being in close proximity of the muscle cells.

At $58 \mathrm{hpf}$, the cytoplasm of the basal epidermal layer cells is enriched with mitochondria, RER cisternae and secretory granules containing a thin fibrillar material. Some of these granules are seen merging to the cell membrane facing the subepidermal space (Fig. $1 \mathrm{~K})$. Some isolated fibroblast-like cells, which we call from now on dermal endothelial cells, are observed at the surface of the muscle cells.

\section{Thickening of the primary dermal stroma during larval stages}

At $72 \mathrm{hpf}$, the skin of the larvae has not changed much compared to the previous stage (Fig. 2A). In the two epidermal layers the cells now contain bundles of microfilaments (Fig. 2B). New matrix has been added to the primary dermal stroma of the dermis, but the diameter of the collagen fibrils $(22 \mathrm{~nm})$ has not changed. In other regions of the skin the organisation of the collagen fibrils has been slightly modified, in that two orientations of the fibrils are observed, at a right angle to each other (Fig. 2B). Except rare pigment cells, no other cells are visible within the primary dermal stroma. In some areas, scarce, flat and elongated, dermal endothelial cells line the surface of the muscle cells. The granular material observed in the lamina lucida of the basement membrane is abundant (Fig. 2C).

At $96 \mathrm{hpf}(4 \mathrm{dpf})$ the epidermal basal layer cells are still rich in organelles, while new collagen fibrils have been added in the primary dermal stroma (Fig. 2 D,E). Also, dermal endothelial cells are more frequently observed at the muscle cell surface, lining the deep surface of the collagen matrix (Fig. 2D).

In $5 \mathrm{dpf}$ (120 hpf) larvae some changes are observed in the structure of the epidermis and the dermis. The basal epidermal layer cells are more flattened and their cytoplasm is more electron dense than before. These cells are relatively poor in organelles, but large bundles of microfilaments are visible, especially in the region facing the dermis where they are anchored to the cell membrane by hemidesmosomes. The basement membrane lining the epidermal basal cells is thicker than previously and numerous adepidermal granules are observed in the lamina lucida (Fig. 2 F,G). The primary dermal stroma forms a regular layer that does not contain any cell body or cell prolongation. Its deep surface is lined by a layer of dermal endothelial cells that cover the muscle cells on most of their surface. The dermal endothelial cells are clearly linked to one another by desmosomes (Fig. 2F). However, occasionally the primary dermal stroma is still in direct contact with the muscle cell surface (Fig. 2H).

\section{Formation of the plywood-like arrangement in the dermis of juve- niles}

In $10 \mathrm{dpf}$ zebrafish, the skin is separated only by a short distance from the well-differentiated muscle cell surface (Fig. 3A). The basal layer cells of the epidermis are still rich in bundles of microfilaments (Fig. 3B). The deep surface of the primary dermal stroma is often lined by a layer of dermal endothelial cells (Fig. 3 B,F), some of which show an intense activity of protein synthesis (Fig. 3F).
However, in some regions, the deep surface of the primary dermal stroma is still in direct contact with the muscle cell surface (Fig. 3C). A remarkable change in the organisation of the primary dermal stroma, however, has occurred in the dermis between 5 and 10 days of development. Indeed, the collagen fibrils of the upper region of the dermis have changed their spacing, orientation and organisation. From a loose primary dermal stroma composed of irregularly-spaced fibrils, mostly oriented parallel to the anteroposterior axis, it has now turned into a dense, regularly spaced network of collagen fibrils. The fibrils are organised into two to three layers, regrouped into the so-called lamellae, with a fibril orientation parallel to the skin surface (Fig. 3 D,E,F). These lamellae show an orthogonal orientation of the fibrils with respect to each other. The fibril diameter $(22 \mathrm{~nm})$ remains unchanged, but the distance between them is now regular $(20 \mathrm{~nm})$. Except for some scarcely distributed pigment cells, the primary dermal stroma is, however, still acellular.

During the following days of development, the orthogonal arrangement extends deeper within the primary dermal stroma when new collagen fibrils are added. In $15 \mathrm{dpf}$ zebrafish, the epidermis has thickened and a third layer is formed. A few specialised clear cells (mucous goblet cells) have differentiated and are actively involved in protein synthesis as demonstrated by the amount of organelles, such as RER cisternae and Golgi regions. The basal epidermal layer cells are still rich in large bundles of microfilaments (Fig. $3 \mathrm{G}, \mathrm{H}$ ). The primary dermal stroma is characterised, throughout its thickness, by the orthogonal arrangement of several lamellae of collagen fibrils, the diameter of which is unchanged compared to the previous stages. The deep surface of the dermis is irregularly lined by melanophores and plump, adjacent dermal endothelial cells. The latter have a cytoplasm rich in mitochondria, ribosomes, RER cisternae and secretory granules (Fig. $3 \mathrm{G}, \mathrm{H}$ ).

At $20 \mathrm{dpf}$, the skin features described at $15 \mathrm{dpf}$ have become more pronounced. The basal epidermal cells are richer in bundles of microfilaments (Fig. $3 \mathrm{I}, \mathrm{J}$ ). The primary dermal stroma is thicker and the number of orthogonal collagen lamellae has increased. The characteristics of the collagen fibrils are nevertheless conserved, i.e., a $22 \mathrm{~nm}$ diameter and a regular spacing (Fig. $3 \mathrm{~J}, \mathrm{~K}$ ). Moreover, in certain areas, this regularly organised primary dermal stroma is penetrated by vertical bundles of collagen fibrils originating from the deep region of the dermis and reaching the deep surface of the subepidermal basement membrane (Fig. 3J). These vertical bundles are lined by elongated cytoplasmic prolongations of the dermal endothelial cells bordering the deep region of the dermis (Fig. 3J). These cells, which are connected by short desmosomes now constitute an uninterrupted layer covering the surface of the muscle cells. The features of their cytoplasm indicates that they are actively involved in protein synthesis. However, the primary dermal stroma is still acellular throughout its entire thickness, except at the level of the vertical bundles.

\section{Remodelling of the primary dermal stroma in old juveniles and adults}

Remarkable changes are observed in the skin organisation of 26 dpf zebrafish. First, the skin is now composed of four cell layers, significantly increasing its thickness to $14 \mu \mathrm{m}$ in average (Fig. 4A). The superficial layer cells show a clear cytoplasm and are poor in organelles. A few mucous goblet cells are visible in between the intermediate layers. The basal layer cells are distinct from the cells 

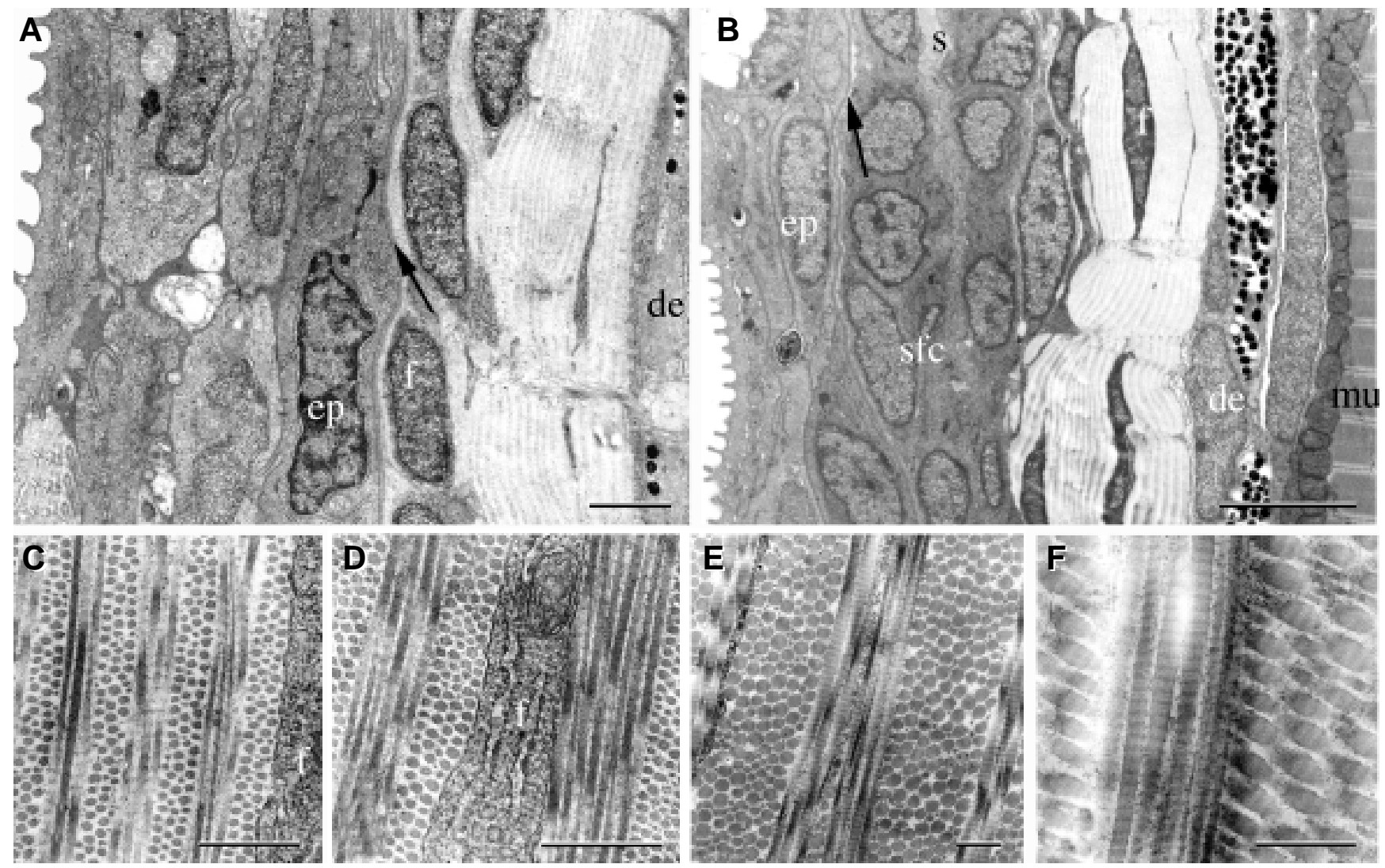

Fig. 4. Invasion of the primary dermal stroma by fibroblasts and collagen remodelling. (A) 26 dpf juvenile. The epidermis is at least four cell layers thick. The basal layer cells show a well-differentiated cytoplasm in which the bundles of microfilaments are no longer visible. Fibroblast-like cells have invaded the collagenous stroma (stratum compactum of the dermis) and some have accumulated along the basement membrane. (B) $30 \mathrm{dpf}$. Immediately below the basement membrane a scale-forming cell population (a scale papilla) has differentiated from the invading fibroblasts. The first matrix of a scale has already been deposited (arrow). Fibroblasts are still present within the collagenous matrix of the stratum compactum. Its deep surface is lined by the bilayered dermal endothelium, in which pigment cells are located. (C-F) These micrographs illustrate the changes occurring in the stratum compactum of the dermis during subsequent growth. (C) 30 day-, (D) 3 month-, (E) 2 year-, (F) 4 year-old specimens. Abbreviations: de, dermal endothelial cells; ep, epidermis; f, fibroblast; mu, muscle cells; s, scale; sfc, scale-forming cells. Scale bars: A, $2 \mu \mathrm{m} ; B, 5 \mu \mathrm{m} ; C-F, 500 \mathrm{~nm}$.

of the other epidermal layers in being roughly cuboidal and in having an electron-dense cytoplasm. The bundles of microfilaments have disappeared from the region facing the dermis and are replaced by an abundant network of RER cisternae, Golgi regions and mitochondria. Some small vesicles are seen to be fused to the cell membrane facing the dermis. The latter has thickened to an average of $5 \mu \mathrm{m}$, and it is characterised by the presence of numerous fibroblasts between the collagen lamellae. The cells are oriented with their long axis parallel to the fibril orientation (Fig. 4A). The change, at $26 \mathrm{dpf}$, from an acellular to cellular dermis reflects a major modification in the skin organisation. The primary dermal stroma has changed into a secondary dermal stroma, also called stratum compactum. The fibroblasts located in its deep region are flat and elongated, while those in the upper layers close to the epidermis are plump, possess a large nucleus and a cytoplasm rich in RER cisternae, Golgi apparatus and mitochondria. At the deep surface of the stratum compactum, the layer of dermal endothelial cells is flat and delimits the deep dermal region, in which pigment cells are visible, from the muscle cells. This region, considered as the initium of the hypodermis, has been described by Whitear etal. (1980) in numerous teleost species. The last change concerns also the dermis, in which the plywood-like stratum compactum is now composed of collagen fibrils of a larger diameter than in the previous stages, about $50 \mathrm{~nm}$.

At $30 \mathrm{dpf}$ the upper region of the dermis has been modified in relation to scale development (Fig. 4B). Scale-forming cells have differentiated from the fibroblast population that has accumulated close to the epidermal cells. Dermal papillae have formed at specific loci, and scales are developing inside such papillae (see detailed descriptions by Sire and Géraudie, 1983, Sire et al., 1997, and Sire and Amimenko, 2004). Scale development and growth take place in the upper part of the dermis (the so-called stratum laxum). Below the scale, the dermis is constituted by the stratum compactum characterized by a plywood-like organisation. This region contains numerous fibroblasts, distributed amongst a collagenous network showing a remarkably constant fibril diameter of $50 \mathrm{~nm}$ (Fig. 4C).

During further growth, the collagenous stroma of the stratum compactum does not change its organisation, but, interestingly, the diameter of the collagen fibrils increases with time. We have recorded the fibril diameter for each stage of development and the results are expressed as minimum and maximum values, to better reveal the heterogeneity of fibril diameter in some stages (Fig. 5). During the first ten days of development, the collagen fibrils show a constant diam- 


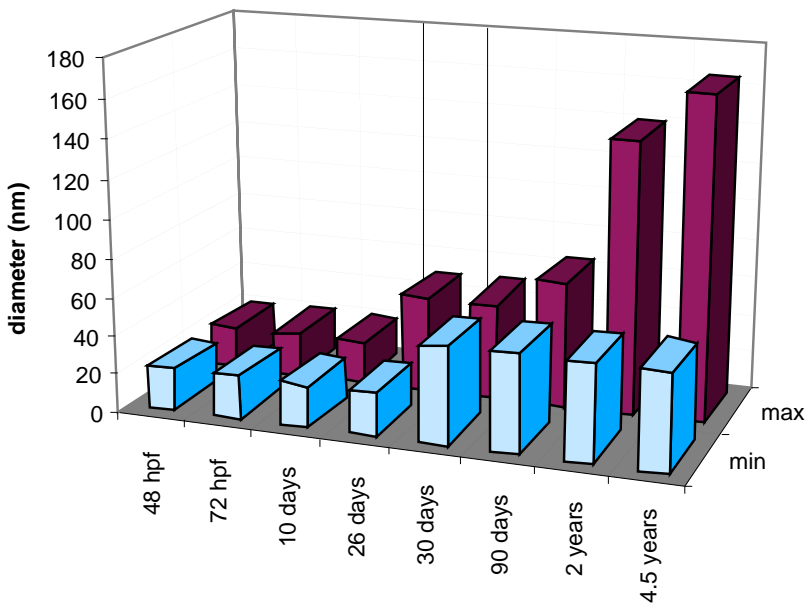

Age of zebrafish

Fig. 5. Diameter (minimum and maximum values) of the collagen fibrils in the dermis of zebrafish during ontogeny. The $22 \mathrm{~nm}$ diameter of the fibrils remains unchanged during the first 10 days of development; it then increases from 26 dpf onwards. This stage corresponds to the invasion of the collagenous stroma by fibroblasts. From $90 \mathrm{dpf}$ onwards, the variability of the collagen fibril diameter also increases.

eter of $22 \mathrm{~nm}$ without any variation. A similar value has been measured in 20 dpf specimens, but not statistically recorded at this stage. At $26 \mathrm{dpf}$ the fibril diameter increases significantly, with a mixture of $22 \mathrm{~nm}$ and $50 \mathrm{~nm}$ fibril diameter. Interestingly, this increase of diameter is concomitant with the invasion of the stratum compactum by fibroblasts. At $30 \mathrm{dpf}$, when the scales are developing, the collagen fibrils show a constant diameter of $50 \mathrm{~nm}$ (with only a few 22 $\mathrm{nm}$ diameter fibrils). At $90 \mathrm{dpf}$, when sexual maturity is reached, the fibril diameter ranges from 50 to $70 \mathrm{~nm}$ (Fig. 4D). In 2 year-old specimens, although some fibrils are $50 \mathrm{~nm}$ in diameter numerous reach $140 \mathrm{~nm}$ (Fig. 4E, 5). In 4.5 year-old zebrafish (a very advanced age for zebrafish), the maximum fibril diameter is close to $160 \mathrm{~nm}$ (Fig. 4F, 5).

\section{The origin of the collagenous stroma}

From $24 \mathrm{hpf}$, the first stage in which collagens fibrils are observed in the subepidermal space, to about $26 \mathrm{dpf}$, when the fibroblasts invade the plywood-like stratum compactum, the matrix below the epidermis is strictly acellular. One $\mu \mathrm{m}$-thick sections obtained from 48 hpf whole-mount hybridised embryos reveal Co/1a2 trancripts (Fig. 6 A,B). Although it is sometimes difficult to distinguish, detailed

Fig. 6. Col1a2mRNA localisation in the skin of $48 \mathrm{hpf}$ embryos (A-C) and 30 day-old juvenile (D-F) zebrafish. The 48 hpf embryos are from whole mounts, hybridised with a digoxygenin labelled Col1 a2 antisense RNA probe. Sections of 30 day old zebrafish are hybridised with a ${ }^{35} \mathrm{~S}$ labelled Col1a2 cRNA probe. (A) Cross section at the level of the yolk extension. (B) Cross section at the level of the anal fin. (C) High magnification showing the labelling in the cytoplasm of the epidermal cells. The arrow indicates the epidermal-dermal boundary. (D) The fibroblasts (arrows) located within the collagenous stroma are strongly labelled. No signal above the background is detected in the epidermal cells. (E) Region in which a scale is developing. Transcripts are seen in the scale-forming cells (white arrowheads). (F) Within the collagenous stroma all the fibroblasts (arrow) are labelled. In addition, the dermal endothelial cells (arrowheads) located at the deep surface of the dermis are labelled. Scale bars: A, B, $100 \mu \mathrm{m} ; C$ to F, $50 \mu \mathrm{m}$. observations indicate that the labelled mRNAs are located in the cytoplasm of the epidermal cells (Fig. 6C). Hybridised sections of 30 dpf juveniles show a clear label within the collagenous stroma, while the epidermal cells no longer express Col1a2 (Fig. 6 D-F). The transcripts are located in elongated fibroblasts, in scale-forming cells and in the dermal endothelial cells lining the deep surface of the dermis.

To identify more precisely the location of the Col1a2 mRNAs during the first days of development, we have performed ultrastructural ISH on $72 \mathrm{hpf}$ embryos. Labelling is found in the epidermis with a higher intensity of the signal in the basal layer cells (Fig. 7 A,B). Transcripts are located in the cytoplasm, close to the cisternae of RER. A hybridisation signal is also detected in the dermal endothelial cells located at the surface of the muscle cells (Fig. 7B). At 20 days, when the collagenous stroma is still acellular, gold particles are found both in the epidermal basal cells (figure 7C) and in the endothelial cells (figure 7D). In regions where the dermis is colonised by fibroblasts an intense labelling is observed in these cells, while the signal is less pronounced in the epidermal basal cells and in the endothelium layer (Fig. 7E).

\section{Discussion}

We are thus able to interpret the differentiation of the skin and, particularly, to monitor stepwise the collagen secretion and remodelling of the dermis in this model fish.

\section{The differentiation of the zebrafish skin: a dynamical inter- pretation}

In the zebrafish the first dermal matrix starts to be deposited around $24 \mathrm{hpf}$, when a narrow subepidermal space is created between the epidermis and the surface of the differentiating

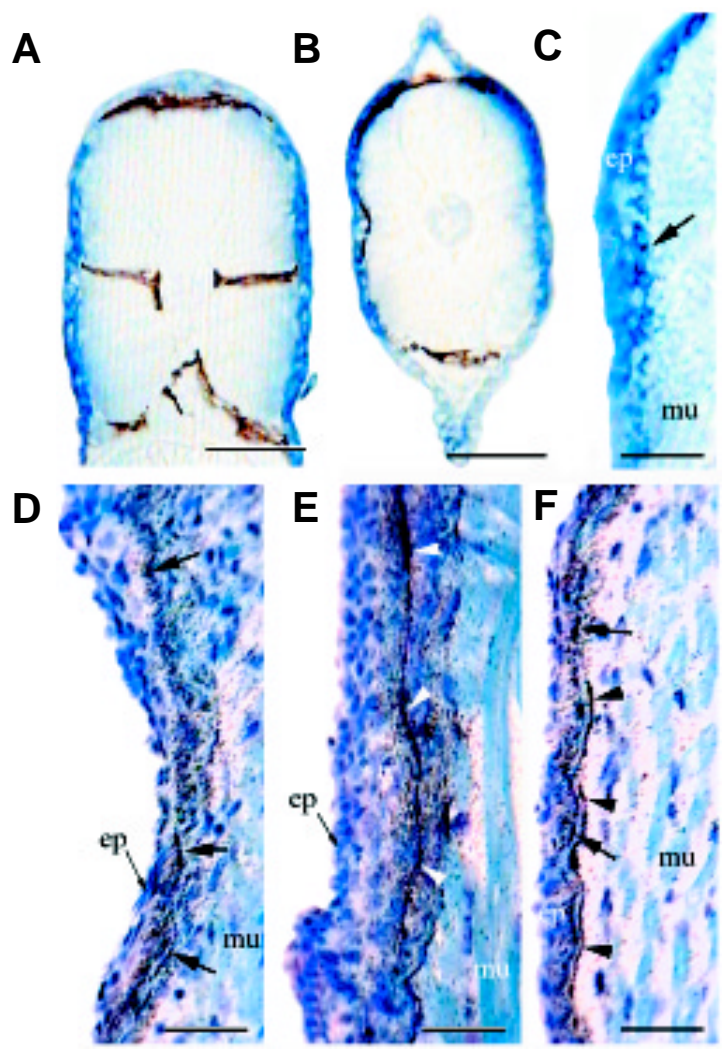



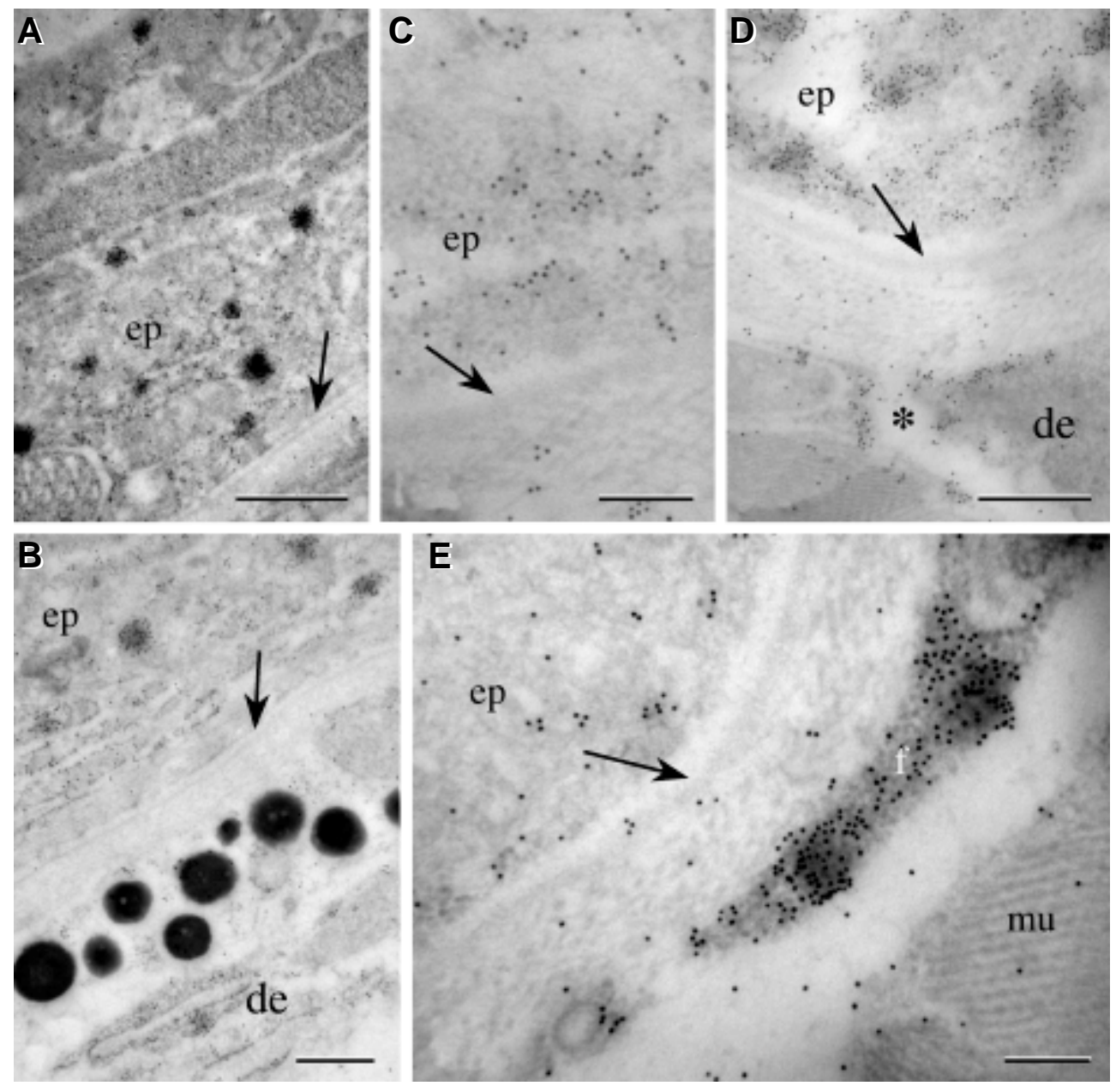

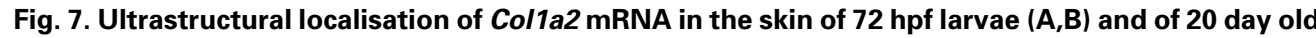
zebrafish (C-E). In all micrographs the arrow indicates the basement membrane. 72 hpfCol1a2 trancripts are clearly detected in both the epidermal cells (A) and the fibroblast-like cells (future dermal endothelium) (B) at the deep surface of the collagenous stroma; $20 \mathrm{dpf}$. Where the dermis is still acellular, Col1a2 trancripts are clearly detected both in the epidermis (C) and in the cells of the dermal endothelium (D). Where fibroblasts have invaded the collagenous stroma, their cytoplasm is intensely labelled (E). Scale bars: $A, 1 \mu m ; B, D, 500$ $\mathrm{nm} ; C, 250 \mathrm{~nm} ; E, 200 \mathrm{~nm}$.

muscle cells. Together with, or soon after, the presence of the first deposited collagenous matrix, the first elements of a basement membrane line the deep surface of the epidermal basal cells. From this initial stage onwards the following morphological changes have been identified in the epidermis, in the subepidermal space and in the deep region of the skin (the future location of the hypodermis), the three tissues involved in skin differentiation.

The epidermis increases to three layers only after the 20th day of development (Fig. 8). The first specialised cells, i.e. mucous cells, only seem to appear by $15 \mathrm{dpf}$, but such cells are present earlier because the skin needs to be protected as soon the fish is hatched. Other specialised features such as the sensory cells are also probably present early during epidermis development. Further studies are needed with respect to elucidating the development of the specialised cell types. During the $24 \mathrm{hpf}$ to $5 \mathrm{dpf}$ period, the cytoplasm of the epidermal cells, mainly that of the basal layer, shows features revealing active protein synthesis. Our in situ hybridisation experiments reveal the presence of Col1a2mRNA in the cytoplasm of the epidermal cells and so confirm that the epidermal cells are involved in collagen production. From 5 to $15 \mathrm{dpf}$ the basal epidermal cells seem to slow down this process. From 15 to $20 \mathrm{dpf}$, their cytoplasm becomes electron-dense and is enriched in microfilaments, features that are typical of quiet basal epidermal cells in fish (Sire et al., 1997). From $26 \mathrm{dpf}$ the basal epidermal cells restart to show an active protein synthesis, concomitant with the presence of fibroblasts in the collagenous stroma, and with scale development. These epidermal features might be related to epidermaldermal interactions (production of signaling molecules) rather than to collagen synthesis (Sire etal., 1997).

The subepidermal space is created before $24 \mathrm{hpf}$ and the first collagenous matrix is distinguishable at that time. During the first five to seven days of development, the primary dermal stroma progressively fills in the subepidermal space that enlarges, and the matrix becomes denser (Fig. 8 A,B). During this period, the collagen fibrils are mostly oriented in the same direction throughout the entire thickness of the primary dermal stroma. Between 7 and 10 days of development, the typical orthogonal (plywood-like) organisation of the matrix appears, first in the upper layers, then throughout the whole primary dermal stroma (Fig. 8C). Remarkably, these changes occur in a space devoid of fibroblasts. Indeed, the primary dermal stroma remains acellular during the first 20-26 days of development. It is noteworthy also that the diameter of the collagen fibrils does not change during the 20 first days of development and remains constant at $22 \mathrm{~nm}$. Starting from 20-26 $\mathrm{dpf}$, the primary dermal stroma is invaded by fibroblasts of unknown origin. However, some pictures indicate that they are not derived from the dermal endothelial layer bordering the deep surface of the primary dermal stroma. Rather, they seem to come from a cell population migrating into the collagenous stroma from the connective tissue septa, particularly at the level of the mid-line (Fig. 8D). Both their initial location, and their involvement in scale formation, indicates that these fibroblasts are possibly derived from a neural crest cell sub-population. The modifications occurring in the dermis at this 20-26 dpf developmental stage lead us to consider the collagenous matrix as the definitive, adult state of the dermis, i.e. the secondary dermal stroma, also called stratum compactum. Interestingly, a clear correlation exists between the penetration of the collagen matrix by the fibroblasts and the 
increase of fibril diameter observed in the subsequent stages of skin development. As expected, our in situ hybridisation experiments also reveal that the fibroblasts embedded in the collagenous stroma are involved in an active secretion of collagen.

The developmental events occurring at the deep surface of the dermis are also relevant. At 24-48 hpf, when the first collagen matrix is deposited in the subepidermal space, the latter is lined at its deep surface by muscle cells. Some mesenchymal cells are scarcely distributed at the surface of the muscle cells. These mesenchymal cells, which show a fibroblastlike aspect, have been interpreted as the precursors of the dermal endothelium that will line the hypodermis in more developed skin. The scarcity of mesenchymal cells at the deep surface of the collagen matrix virtually excludes the possibility that these cells are responsible for the production of the collagenous matrix found in the subepidermal space. From $72 \mathrm{hpf}$ onwards, the number of these dermal endothelial cells increases, and at 20-26 dpf they entirely cover the muscle cell surface. TEM and in situhybridisation experiments reveal that these cells are involved in collagen synthesis as soon as from $72 \mathrm{hpf}$ onwards.

Taken together these results lead us to interpret the sequence of deposition of the collagenous stroma of the dermis as follows: (1) from 24 to $48 \mathrm{hpf}$, the epidermal basal cells produce the collagen matrix; (2) from $72 \mathrm{hpf}$ to $20-26 \mathrm{dpf}$, both the epidermal basal cells and the dermal endothelial cells are involved in collagen production; (3) from 20-26 dpf onwards the epidermal basal cells cease progressively collagen deposition, while the dermal endothelial cells and the fibroblasts contribute to this production.

\section{Collagen deposition by epidermal cells}

The processes described above for fish skin development are remarkably similar to what has been described for the formation of the chick cornea (Hay and Revel, 1969; Hayashi et al., 1988). In three day-old chick embryos, the corneal epithelium secretes the primary corneal stroma. Next, mesenchymal cells destined to become the corneal endothelium invade the area close to the lens. Finally, the corneal stroma is invaded by corneal fibroblasts from the sides of the eye.

It is now well-established that epithelial cells are able to synthesise fibrillar and non-fibrillar collagens, as for type IV collagen in the basement membrane. To our knowledge type IV collagen has not been identified yet in the basement membrane of fish, but, recently, type XVIII collagen, another non-fibrillar com-
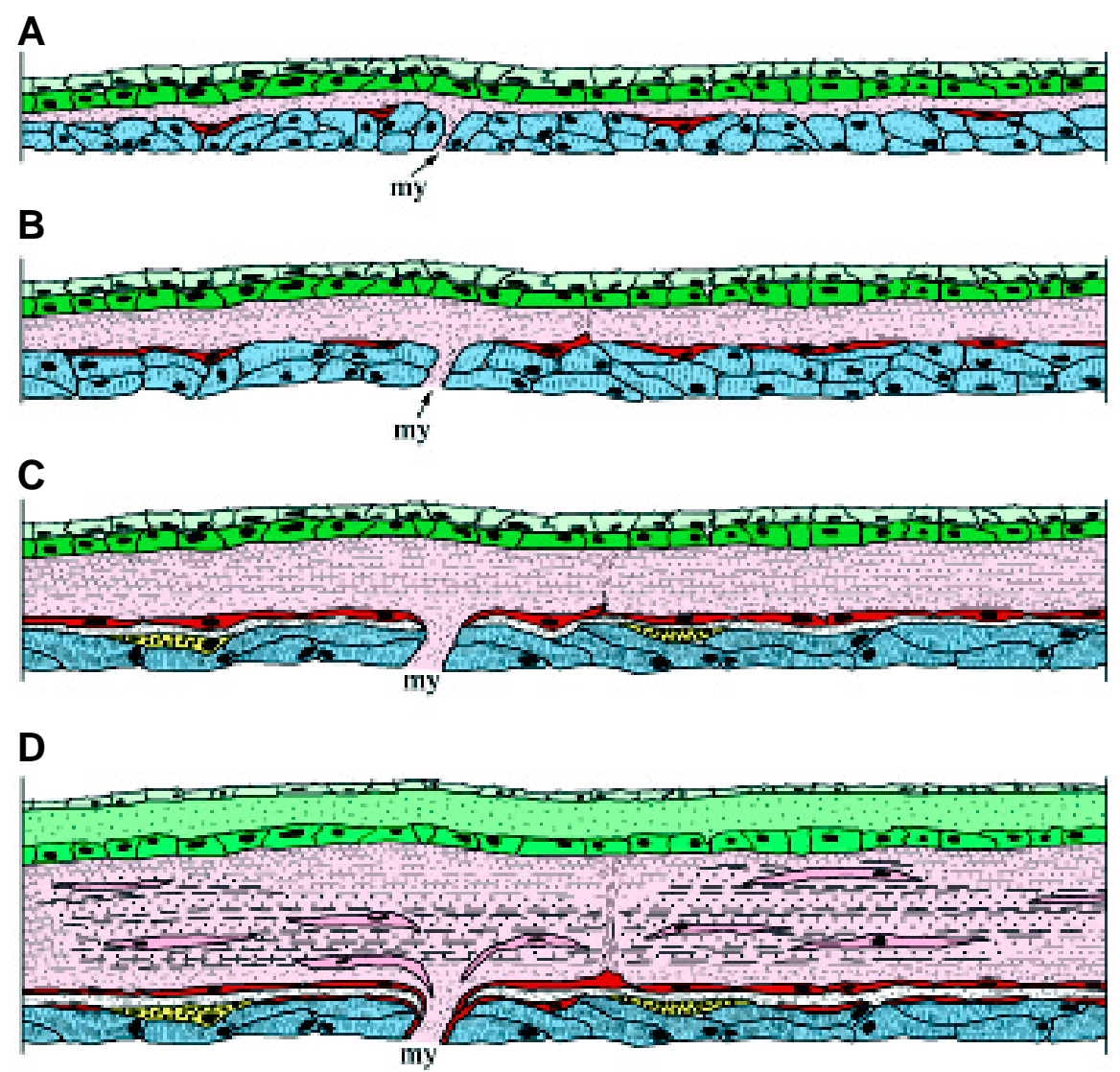

Epidermis

\begin{tabular}{l|l|l|}
$\begin{array}{l}\text { Superficial stratum } \\
\text { Intermediate stratum }\end{array}$ & Dermal stroma & Pigment cell \\
Basal stratum & Fibroblast & Muscle cell \\
Differentiated basal cell & & Dermal endothelium \\
\hline
\end{tabular}

Fig. 8. Interpretative drawings of the various steps of skin development in the zebrafish. Drawn from light and TEM micrographs of longitudinal sections of zebrafish skin from 24 hpf to $26 \mathrm{dpf}$, and including data from Col1a2 in situ hybridisation. (A) First deposition of collagen fibrils. From 24 to 72 hpf, the skin is composed of two strata: the epidermis, composed of two layers, and the epidermal-mesenchymal space which is progressively filled with collagen matrix, constituting the primary dermal stroma. The deep surface of this stroma is bordered by muscle cells and by scarce fibroblast-like cells. Type I collagen is synthesised by the cells of the basal epidermal layer. (B) Thickening of the primary dermal stroma. From $72 \mathrm{hpf}$ to $5 \mathrm{dpf}$, new collagen matrix is produced by the cells of the basal epidermal layer and by the fibroblast-like cells located at its deep surface. The latter will constitute the so-called dermal endothelium of the hypodermis. Some cells of this layer are involved in the production of vertical bundles of collagen fibrils. No cells penetrate the stroma, which remains acellular until $26 \mathrm{dpf}$. (C) Formation of the plywood-like arrangement. From $5 \mathrm{dpf}$ to $20 \mathrm{dpf}$, in the still acellular primary dermal stroma, the collagen fibrils organise progressively into a plywood-like structure, starting from the upper region. The collagen fibrils are arranged into thin layers that are disposed at right one to the other. The stroma has thickened and the hypodermis is formedatits deep surface. (D) Invasion of the primary dermalstromaby fibroblasts and collagen remodelling. This last step is characterised by (1) the differentiation of the intermediate stratum of the epidermis, (2) the invasion of the primary dermal stroma by fibroblasts, which are probably arriving from the myosepta, and (3) the remodelling of the collagen stroma with collagen fibrils increasing in diameter. The cells of the epidermal basal layer no longer synthesise collagen, which is now produced by the fibroblasts that have penetrated the dermal stroma. The cells of the dermal endothelium continue to produce collagen. my, myoseptum. 
ponent of basement membranes, has been shown to be expressed in the epidermis of zebrafish (Haftek et al., 2003) and mouse (Miosge et al., 2003). The results presented here indicate that the epidermal cells are also involved in fish in the production of fibrillar type I collagen in the primary dermal stroma. The interest for the epithelial production of collagen was initiated in a study by Hay and Revel (1963).Working on skin development in the amphibian Ambystoma, these authors suggested that the collagenous matrix of the dermis could be produced by the epidermal basal cells as well as by the fibroblasts. It appears, therefore, that the production of fibrillar collagen by epidermal cells during the initial stages of development is a more common process in vertebrates than hitherto accepted. The production of collagen by epidermal cells of course raises the question of how this collagen crosses the basal lamina. Procollagen is processed into collagen after exocytosis and the assembly steps of the collagen fibrils occur in the subepidermal space. The first step before the formation of collagen fibrils consists of a proteolysis of the procollagen by removal of the $\mathrm{NH}_{2}$ (depending on the collagen type) and $\mathrm{COOH}$ propeptides (Goldberg et al., 1975; Tuderman et al., 1978). Does this proteolysis occur before or after crossing the basal lamina? Are there pores permitting these molecules to cross this boundary? These questions remain to be solved.

These findings raise the so far unsolved question of the genetic control of Col1a2expression in the epidermal cells. In the mouse it is now clear that the dermal fibroblasts influence both proliferation and differentiation of keratinocytes (Ghalbzouri et al., 2002). The growth promoting effect of fibroblasts is induced by unknown soluble factors released from fibroblasts, and no direct keratinocytefibroblast interaction is required. Dealing with the zebrafish skin, we can only state that the end of the production of the collagen by the basal epidermal cells is concomitant with the invasion of the dermal stroma by fibroblasts.

\section{Changes occurring in the dermal stroma}

How can collagen fibrils organise themselves within a subepidermal space devoid of cells? Although the genetics and chemistry of collagen type I are relatively well understood, the assembly of the molecules in a three-dimensional space is not (review in Ploetz et al., 1991). Some in vitro studies of collagen type I fibrillogenesis have indicated that physicochemical forces lead to a self-assembly of the fibrils. In fact, the producing cells could regulate the selfassembly process by the manipulation of the microenvironment and the spatial and temporal determination of the matrix deposition (Ploetz etal., 1991; Veis and George, 1994; Brightman et al., 2000; Forgacs et al., 2003; Holmes et al., 2001). However, the extracellular compartment, over which the cells have an influence is located close to the cell surface, i.e. at the cell-matrix interface (Ploetz et al., 1991). The study of the production of collagen fibrils by the corneal epithelium has revealed how the cells can influence the organisation of the architecture of the matrix by polarized discharge of secretory products (Trelstad, 1970, 1971; Trelstad and Coulombre, 1971). Thus, in the zebrafish skin the self-assembly of the fibrils in the primary dermal stroma could be regulated by the epidermal basal cells only in the vicinity of the basal lamina. This influence of the epidermal cells on a short distance could explain why the diameter of the fibrils remains constant throughout the thickness of the acellular primary dermal stroma. Proteoglycans, are probably also present in the subepidermal space of the developing zebrafish skin, have been shown to influence the fibril formation in vitro (Ruoslahti, 1988; Brown and Vogel, 1990).

The transformation of the dense, homogeneous collagen type I matrix into a plywood-like organisation is also of interest. Ordered arrays of collagen fibrils have already been reported to occur in the dermis of adult species (Junqueira et al., 1983b) and are also known to occur in bone (Ascenzi and Bonucci, 1968), fish scales (Meunier, 1983; Sire, 1987), tendon (Gathercole and Keller, 1978; Birk and Trelstad, 1986) and cornea (Trelstad and Coulombre, 1971). In the latter, the fibrils are grouped as bundles and the bundles are organised into orthogonal lamellae that describe a right-handed spiral resembling a cholesteric liquid crystal (Trelstad et al., 1982). Such a regular arrangement of the fibrils is similar to liquid crystalline orders, and such a plywood-like structure has been obtained in vitro under precise concentration of type I collagen (Giraud-Guille, 1996; Giraud-Guille et al., 2000). This self-organising process has been well studied as a paradigm to understand the formation of the twisted plywood of the collagen matrix in bone (Giraud-Guille, 1996). In vivo, the remodelling observed during zebrafish skin development is probably in relation with the composition of the matrix, that is itself determined by the cells located at the surfaces of the primary dermal stroma, either the epidermal basal cells or the dermal endothelial cells, or both. By enriching the subepidermal space with an increasing concentration of collagenous matrix, the cells located at some distance of the matrix, such as the epidermal basal cells and the dermal endothelial cells in the developing skin, could be responsible for such a physical transformation.

\section{Regulation of the diameter of the collagen fibrils}

From $24 \mathrm{hpf}$ to 20-26 dpf, the uniform $22 \mathrm{~nm}$ diameter of the fibrils, and some time later the uniform interfibrillar spacing, indicates that fibril growth is stabilised. This is once again similar to the description of the chick cornea, in which the collagen fibrils show a uniform diameter and uniform interfibrillar spacing. This stability is given up when the fibroblasts invade the primary dermal stroma at 20-26 dpf and come in close contact with the collagen fibrils. Together with this invasion, the fibril diameter is shown to increase progressively during subsequent fish life. This increase of fibril diameter can be achieved by two well-known processes: accretion of new collagen molecules deposited by the fibroblasts and/or fusion of existing fibrils. Several factors could be involved in the regulation of the fibril diameter. They include glycosylation of the collagen (Ibrahim et Harding, 1990), procollagen processing (Kadler etal., 1990; Romanic etal., 1991), collagen-proteoglycans interactions (Scott, 1986), and interaction between collagen type I and type V (Fitch et al., 1984). Recently, two proteoglycans, lumican and fibromodulin, have been shown to be involved in the stabilisation of the fibril diameter in mediating the entry into the fibril growth (Ezura et al., 2000). The co-assembly of different collagen types to form heterotypic fibrils is another important factor that is known to regulate fibrillogenesis. For example, collagen type I and $\mathrm{V}$ are coassembled in the secondary corneal stroma (Linsenmayer et al., 1985; Fitch et al., 1988; Birk et al., 1988). In the cornea, this assemblage is known to regulate the diameter of the collagen fibrils as demonstrated by in vitro heterotypic fibrillogenesis experiments. These showed that the diameter of the fibrils decreased when the ratio of collagens $\mathrm{V} / \mathrm{I}$ increased (Birk et al., 1990). A portion of the $\mathrm{NH}_{2}$-terminal domain, which is exposed at the 
surface of the molecule, prevents the growth of the fibrils (Linsenmayer et al., 1993). In teleosts, previous biochemical analyses have shown that collagen type I is the prominent component of the elasmoid scales and that it co-exists with the minor type $\mathrm{V}$ (Zylberberg et al., 1992). The occurrence of thin fibrils in the external layer of these scales is thought to be related to a large amount of type $\mathrm{V}$ collagen in this layer (Le Guellec and Zylberberg, 1998). The presence of type $V$ collagen has not been yet demonstrated in the zebrafish skin.

More data are, therefore, necessary to improve our understanding of skin formation in the zebrafish. We need to check whether or not the three $\alpha$ chains of type I collagen that are know to exist in zebrafish (Morvan-Dubois, 2002) are present in the earliest produced collagenous matrix. Similarly, we also need to know whether the other fibrillar type, collagen type $\mathrm{V}$, is synthesised by the epidermal cells at such early steps of development, or whether it is only produced by the fibroblasts once these have invaded the dermal stroma. A number of questions, mainly those concerning the origin of the dermal cells, however, remains unanswered.

\section{Materials and Methods}

Wild type zebrafish were reared at a constant temperature of $28^{\circ} \mathrm{C} \pm$ $0.5^{\circ} \mathrm{C}$. The fish were killed with an overdose of anaesthetic (MS222). Entire fish or skin samples were next immediately immersed in the appropriate fixative. The following growth series was used: 15-, 24-, 32-, 48-, 72-, 96and 120 hours pf, 7-, 10-, 15-, 20-, 26- and 30 days pf, and 3 month-, 2 yearand 4.5 year-old specimens.

For comparative purposes, we have used transverse sections in the same region in all fish examined, i.e., through the anal fin region, and perpendicular to the antero-posterior body axis. However, some sections were made at an angle of $45^{\circ}$ to this axis to examine the $2 \mathrm{D}$ arrangement of the collagen fibrils. In addition, some observations were collected on the skin features in the anterior region of the body.

\section{Transmission electron microscopy (TEM)}

The samples were fixed in a mixture of aldehydes and embedded as previously described (Sire et al., 1997a). They were observed either in a Philips CM120 or Philips 201 electron microscope.

\section{In situ hybridisation (ISH)}

Sense and antisense $\alpha 2(I)$ cRNA riboprobes were prepared by subcloning the cDNA clone Colz1800 coding for the C-terminal region of the $\alpha 2(I)$ collagen mRNA (Morvan-Dubois et al., 2002) into a Bluescript SK-vector. cRNA probes were labelled either with ${ }^{35} \mathrm{~S}-U T P(1000 \mathrm{Ci} / \mathrm{mmole}$; NEN, Les Ulis, France), or with DIG-11 UTP (Roche Diagnostic, France).

Whole mount ISH was carried out as described by Thisse and Thisse (http://www-igbmc.u-strasbg.fr/zf_info/zbook/chapt9/9.82.html). ISH on tissue sections was carried out as described previously (Le Guellec et al., 1994; Morvan-Dubois et al., 2002).

Embryos were fixed in $4 \%$ formaldehyde in $0.18 \mathrm{M}$ cacodylate buffer $(\mathrm{pH}$ 7.4) and embedded in LR White. Hybridisation and detection of the labelling were carried out as described previously (Le Guellec and Zylberberg, 1998). Thin sections were incubated for $16 \mathrm{~h}$ in the hybridisation buffer $(50 \%$ deionized formamide, 4 x SSC, 10\% dextran sulfate, $1 \times$ Denhardt's solution, $100 \mu \mathrm{g} / \mathrm{ml}$ salmon sperm DNA) containing $10 \mu \mathrm{g} / \mathrm{ml}$ of biotinylated cRNA probe. Rinses were for $2 \times 5 \mathrm{~min}$ in PBS. To detect the labelling, grids were incubated for $15 \mathrm{~min}$ in $0.1 \mathrm{M}$ phosphate buffer, $\mathrm{pH} 7.4$, containing $0.65 \mathrm{M} \mathrm{NaCl}, 0.05 \%$ Tween 20 and $0.5 \%$ ovalbumin (buffer $\mathrm{A}$ ), then for $2 \mathrm{~h}$ in rabbit anti-biotin serum (ENZO Biochem, New York, USA), and rinsed for $15 \mathrm{~min}$ in the same buffer. The grids were subsequently incubated for 15 min in $0.02 \mathrm{M}$ Tris- $\mathrm{HCl} \mathrm{pH} 7.6,0.65 \mathrm{M} \mathrm{NaCl}, 0.05 \%$ Tween 20 , and $0.5 \%$ ovalbumin (buffer B), then for $30 \mathrm{~min}$ in anti-rabbit serum conjugated with gold particles of $15 \mathrm{~nm}$ (Biocell, Cardiff, UK) and rinsed for $15 \mathrm{~min}$ in the same buffer. Thin sections were deposited for $10 \mathrm{~min}$ on a drop of $2 \%$ glutaraldehyde in PBS, rinsed briefly in distilled water, and stained with uranyl acetate.

\section{Acknowledgements}

We are grateful to Prof. Ann Huysseune (Ghent University, Belgium) for helpful criticism of the manuscript and English editing. We thank Françoise Allizard, Maryline Malbouyres and Hélène Perrin for technical assistance, and Alain Bosch for photographic assistance. This work was supported by a "Bonus Qualité Recherche" grant from Claude Bernard University and a grant from "la Ligue contre le cancer" (DL) and by the CNRS FRE 2696 (JYS). The electron microscopical observations were done at the "Centre des Microstructures", Claude Bernard University, Lyon, and at the "Service de Microscopie électronique de l'IFR de Biologie Intégrative, "Paris.

\section{References}

ASCENZI, A., and BONUCCI, E. (1968) The compressive properties of single osteons. Anat. Rec., 161: 377-392.

BIRK, D.E. and TRELSTAD, R.L. (1986). Extracellular compartments in tendon morphogenesis: collagen fibril, bundle, and macroaggregate formation. J. Cell Biol., 103: 231-240.

BIRK, D.E., FITCH, J.M., BABIARZ, J.P. and LISENMAYER, T.F. (1988). Collagen type I and type $V$ are present in the same fibril in the avian corneal stroma. J Cell Biol., 106: 999-1008.

BIRK, D.E., FITCH, J.M., BABIARZ, J.P., DOANE, K.J. and LINSENMAYER, T.F. (1990). Collagen fibrillogenesis in vitro: interaction of type I and V collagen regulates fibril diameter. J. Cell Sci, 95: 649-657.

BRIGHTMAN, A.O., RAJWA, B.P., STURGIS, J.E., McCALLISTER, J.P., ROBINSON J.P. and VOYTIK-HARBIN, S.L. (2000) Time-lapse confocal reflection microscopy of collagen fibrillogenesis and extracellular matrix assembly in vitro. Biopolymers, 54: 222-234.

BURDAK, V.D. (1979) Morphologie fonctionnelle du tégumentécailleux des poissons La Pensée Scientifique, Kiev (en russe), traduction française, Vol. spécial, Cybium, 10, $145 \mathrm{p}$

EZURA, Y., CHAKRAVARTI, S., OLDBERG, A., CHERVONEVA, I. and BIRK, D.E. (2000). Differential expression of lumican and fibromodulin regulate collagen fibrillogenesis in developing mouse tendons. J. Cell Biol., 151: 779-787.

FISHBASE (2002) FishBase 2002 (CD-ROM). ICLARM, Manille.

FISHELSON, L. (1984) A comparative study of ridge-mazes on surface epithelial cellmembranes of fish scales (Pisces, Teleostei). Zoomorphology, 104: 231-238.

FITCH, J.M., GROSS J., MAYNE, R., JOHNSON-WINT B., and LINSENMAYER, T.F. (1984) Organization of collagen types I and $V$ in the embryonic chicken cornea: Monoclonal antibody studies. Proc. Natl. Acad. Sci. USA., 81: 2791-2795.

FITCH, J.M., BIRK, D.E., MENTZER, A., HASTY, K.A., MAINARDI, C and LINSENMAYER, T.F. (1988). Corneal collagen fibrils: Dissection with specific collagenases and monoclonal antibodies. Invest. Ophthalmol. Vis. Sci., 29:112536

FORGACS, G., NEWMAN, S.A., HINNER, B., MAIER, C.W. and SACKMANN E. (2003) Assembly of collagen matrices as a phase transition revealed by structural and rheologic studies. Biophys. J., 84: 1272-1280.

FUJII, R. (1968) Fine structure of the collagenous lamella underlying the epidermis of the goby, Chasmichthys gulosus. Annot. Zool. Jpn, 41: 95-106.

GATHERCOLE, L.J. and KELLER, A. (1978) Early development of crimping in rat tail tendon collagen: a polarizing optical and SEM study. Micron, 9: 83-89.

GHALBZOURI, A.E.L., GIBBS, S., LAMME, E., van BLITTERSWIJK, C.A. and PONEC, M. (2002). Effect of fibroblasts on epidermal regeneration. Br. J. Dermatol., 147: 230-243.

GIRAUD-GUILLE, M.M. (1996) Twisted liquid crystalline supramolecular arrangements in morphogenesis. Int. Rev. Cytol., 166: 59-101.

GIRAUD-GUILLE, M.M., BESSEAU, L., CHOPIN, C., DURAND, P. and HERBAGE, D. (2000) Structural aspects of fish skin collagen which forms ordered arrays via liquid crystalline states. Biomaterials, 21: 899-906. 
GOLDBERG, A.L., MARTEL, S.B. and HUSHMERIK, M.J.(1975) In vitro preparations of the diaphragm and other skeletal muscles. Methods Enzymol. 39:82-94

HAFTEK, Z., MORVAN-DUBOIS, G., THISSE, B., THISSE, C., GARRONE, R. and LE GUELLEC, D. (2003) Sequence and embryonic expression of collagen XVIII NC1 domain (endostatin) in the zebrafish. Gene Exp. Pathol., 3: 351-354.

HAWKES, J.W. (1974) The structure of fish skin. I. General organization. Cell Tissue Res., 149: 147-158.

HAY, E.D. and REVEL J.P. (1963) Autoradiographic studies of the origin of the basement lamella in Ambystoma. Dev. Biol., 7: 152-168.

HAY, E.D. and REVEL, J.P. (1969) Fine structure of the developing avian cornea. I $r$. Monographs in Developmental Biology (Wolski, A. \& Chen P.S., eds) vol. 1: 1-144. Karger AG., Basel, Switzerland.

HAYASHI, M., NINOMIYA, Y., HAYASHI, K., LINSENMAYER, T.F., OLSEN, B.R. and TRELSTAD, R. (1988) Secretion of collagen types I and II by epithelial and endothelial cells in the developing chick cornea demonstrated by in situ hybridization and immunohistochemistry. Development, 103: 27-36.

HOLMES, D.F., GRAHAM, H.K., TROTTER, J.A. and KADLER, K.E. (2001) STEM/ TEM studies of collagen assembly. Micron, 32: 273-285.

IBRAHIM, J and HARDING, J.J. (1989) Pinpointing the sites of hydroxylysine glycosides in peptide alpha 1-CB7 of bovine corneal collagen, and their possible role in determining fibril diameter and thus transparency. Biochim. Biophys. Acta, 992: 9-22.

JUNQUEIRA, L.C.U, JOAZEIRO, P.P., MONTES, G.S., MENEZES, N. AND PEREIRA-FILHO, M. (1983a) The collagen fiber architecture of Brazilian naked catfish skin. Brazil. J. Med. Biol. Res., 16: 313-316.

JUNQUEIRA, L.C.U, MONTES, G.S., MARTINS, J.E.C. AND JOAZEIRO, P.P. (1983b) Dermal collagen distribution: A histochemical and ultrastructural study. Histochemistry, 79: 397-403.

KADLER, K.E., HOJIMA, Y. and PROCKOP, D.J. (1990) Collagen fibrils in vitro grow from pointed tips in the $\mathrm{C}$ - to N-terminal direction. Biochem. J., 268:339343.

KEENE, D.R., SAKAI, L.Y., BACHINGER, H.P. and BURGESON, R.E. (1987) Type III collagen can be present in banded collagen fibrils regardless of fibril diameter. J. Cell Biol., 105: 2393-2402.

KEMP, N.E. (1959) Development of the basement lamella of larval anuran skin. Dev. Biol., 1: 459-476.

KIMURA, S. (1985) The interstitial collagens of fish: In: Biology of Invertebrate and Lower Vertebrate Collagens (Bairati, A. \& R. Garrone, eds), pp. 135-155. Plenum Press, New-York.

KIMURA, S. and OHNO, Y. (1987) Fish type I collagen: Tissue-specific existence of two molecular forms, $(\alpha 1) 2 \alpha 2$ and $\alpha 1 \alpha 2 \alpha 3$, in Alaska Pollack. Comp. Biochem. Physiol., 88B: 409-413.

KIMURA, S., OHNO, Y., MIYAUCHI, Y. and UCHIDA, N. (1987) Fish type I collagen: Wide distribution of an $\alpha 3$ subunit in teleosts. Comp. Biochem. Physiol., 88B: 27-34.

KIMURA, S., ZHUM, X.P., MATSUI, R., SHIJOH, M. and TAKAMIZAWA, S. (1988) Characterization of fish muscle type I collagen. J. Food Sci., 53: 1315-1318.

LE GUELLEC, D., MALLEIN-GERIN, F., TREILLEUX, I., BONAVENTURE, J., PEYSSON, P. and HERBAGE, D. (1994) Localization of the expression of types I-III collagen genes in human normal and hypochondrogenesis cartilage canals. Histochem. J., 26: 695-704.

LE GUELLEC, D. and ZYLBERBERG, L. (1998) Expression of type I and type V collagen mRNAs in the elasmoid scales of a teleost fish as revealed by in situ hybridization. Connect. Tissue Res., 34: 257-267.

LELE, Z. and KRONE, P.H. (1997) Expression of genes encoding the collagenbinding heat shock protein (Hsp47) and type II collagen in developing zebrafish embryos. Mech. Dev., 61: 89-98.

LINSENMAYER, T.F., FITCH, J.M., GROSS, J. and MAYNE, R. (1985) Are collagen fibrils in the developing avian cornea composed of two different collagen types? Evidence from monoclonal antibody studies. Ann. N. Y. Acad. Sci., 460: 232-245.

LINSENMAYER, T.F., GIBNEY, E., IGOE, F., GORDON, M.K., FITCH, J.M., FESSLER, L.I. and BIRK, D.E. (1993) Type V collagen: molecular structure and fibrillar organization of the chicken $\alpha 1(\mathrm{~V}) \mathrm{NH} 2$ terminal domain, a putative regulator of corneal fibrillogenesis. J. Cel/ Biol., 121: 1181-1189.
MEUNIER, F.J. (1983) Les tissus osseux des Ostéichthyens. Structure, genèse, croissance et évolution. Archives et Documentations, Micro-Edition, Institut d'Ethnologie, Museum Nationald'Histoire Naturelle, Paris, SN82-600-328, 200 p.

MIOSGE, N., SIMNIOK, T., SPRYSCH, P. and HERKEN, R. (2003) The collagen type XVIII endostatin domain is co-localized with perlecan in basement membranes in vivo. J. Histochem. Cytochem., 51: 285-296.

MORVAN-DUBOIS, G., HAFTEK, Z., CROZET, C., GARRONE, R. and LE GUELLEC, D. (2002) Structure and spatio-temporal expression of the full length DNA complementary to RNA coding for $\alpha 2$ type I collagen of zebrafish. Gene, 294: 55-65.

MORVAN-DUBOIS, G., LE GUELLEC, D., GARRONE, R., ZYLBERBERG, L. and BONNAUD, L. (2003) Phylogenetic analysis of vertebrate collagens locates the position of zebrafish $\alpha 3(\mathrm{I})$ and suggests an evolutionary link between $\alpha$ chains and Hox clusters. J. Mol. Evol. 57: 501-514.

MURRAY, H.M., HEW C.L. and FLETCHER, G.L. (2002) Skin-type antifreeze protein expression in integumental cells of larval winter flounder. J. Fish Biol. 60: 1391-1406.

NADOL, J.B., GIBBONS, J.R. and PORTER, K.R. (1969) A reinterpretation of the structure and development of the basement lamella: an ordered array of collagen in fish skin. Dev. Biol., 20: 304-331.

NAGAI, T., ARAKI, Y. and SUZUKI, N. (2002) Collagen of the skin of ocellate puffer fish (Takifugu rubripes). Food Chem., 78: 173-177.

PFEIFFER, W., SASSE, D. and ARNOLD, M. (1971) Die Schreckstoffzellen von Phoxinus phoxinus und Morulius chrysophakedion (Cyprinidae, Ostariophysi, Pisces). Z. Zellforsch. michrosk. Anat., 118: 203-213.

PLOETZ, C., ZYCBAND, E.I. and BIRK, D.E. (1991) Collagen fibril assembly and deposition in the developing dermis: Segmental deposition in extracellular compartments. J. Struct. Biol., 106: 73-81.

QUILHAC, A. and SIRE, J.-Y. (1999) Spreading, proliferation and differentiation of the epidermis after wounding a the cichlid fish, Hemichromis bimaculatus. Anat. Rec., 254: 435-451.

ROMANIC, A.M., ADACHI, E., KADLER, K.E., HOJIMA, Y. and PROCKOP, D.J. (1991) Copolymerization of pNcollagen III and collagen I. pNcollagen III de creases the rate of incorporation of collagen I into fibrils, the amount of collagen I incorporated, and the diameter of the fibrils formed. J Biol Chem., 266: 1270312709

RUOSLAHTI, E. (1988) Structure and biology of proteoglycans. Ann. Rev. Cell Biol., 4: 229-255.

SAITO, M., TAKENOUCHI, Y., KUNISAKI, N. and KIMURA, S. (2001) Complete primary structure of rainbow trout type I collagen consisting of $\alpha 1(\mathrm{I}) \alpha 2(\mathrm{I}) \alpha 3(\mathrm{I})$ heterotrimers. Eur. J. Biochem., 268: 2817-2827.

SATO, K., YOSHINAKA, R., ITOH, Y and SATO, M. (1989) Molecular species of collagen in the intramuscular connective tissue of fish. Comp. Biochem. Physiol. 92B: 87-91.

SCHMITZ, B., PAPAN, C. and CAMPOS-ORTEGA, J.A. (1993) Neurulation in the anterior trunk region of the zebrafish Brachydanio rerio. Roux's Arch. Dev. Biol. 202: 250-259.

SCOTT, J.E. (1986) Proteoglycan-collagen interaction. Ciba. Found. Symp., 124: 104-124.

SIRE, J.-Y. (1986) Ontogenic development of surface ornamentation in the scales of Hemichromis bimaculatus (Cichlidae). J. Fish. Biol., 28: 713-724.

SIRE, J.-Y. (1987) Structure, formation et régénération des écailles d'un poisson téléostéen, Hemichromis bimaculatus (Perciforme, Cichlidé). Thèse de Doctorat ès-Sciences, Univ. Paris VII, Arch. Doc., Micro-édition, Institut d'Ethnologie, MNHN, SN 87600 449, 261 p.

SIRE, J.-Y. and GERAUDIE, J. (1983) Fine structure of the developing scale in the cichlid Hemichromis bimaculatus (Pisces, Teleostei, Perciformes). Acta Zool. (Stockh.), 64: 1-8.

SIRE, J.-Y. and HUYSSEUNE, A. (2003) Formation of skeletal and dental tissues in fish: A comparative and evolutionary approach. Biol. Rev., 78: 219-249.

SIRE, J.-Y., ALLIZARD, F., BABIAR, O., BOURGUIGNON, J. and QUILHAC, A (1997) Scale development in zebrafish (Danio rerio). J. Anat., 190: 545-561.

SIRE, J.-Y. and AKIMENKO, M.-A. (2004). Scale development in fish: a review with description of sonic hedgehog (shh) expression in the zebrafish (Danio rerio). Int. J. Dev. Biol. 48: 233-247. 
TOUHATA, K., TANAKA, H., YOKOYAMA, Y., SAKAGUCHI, M. and TOYOHARA, $\mathrm{H}$. (2001) Structure of a full-length cDNA clone for the pro- $\alpha 1(\mathrm{~V} / \mathrm{XI})$ collagen chain of red sea bream. Bioch. Biophys. Acta, 1517: 323-326.

TRELSTAD, R. (1970) The golgi apparatus in chick corneal epithelium: Changes in intracellular position during development. J. Cell Biol., 45: 34-42.

TRELSTAD, R. (1971) Vacuoles in embryonic chick corneal epithelium, an epithelium which produces collagen. J. Cell Biol., 48: 689-694.

TRELSTAD, R., BIRK, D.E. and SILVER, F.H. (1982) Collagen fibrillogenesis in tissues, in a solution and from modeling: A synthesis. J. Invest. Dermatol., 79: 109-112.

TRELSTAD, R. and COULOMBRE, A.J. (1971) Morphogenesis of the collagenous stroma of the chick cornea. J. Cell Biol., 50: 840-858.

TUDERMAN, L., KIVIRIKKO, K.I. and PROCKOP, D.J. (1978) Partial purification and characterization of a neutral protease which cleaves the $\mathrm{N}$-terminal propeptides from procollagen. Biochemistry, 17: 2948-54.

VEIS, A. and GEORGE, A. (1994) Fundamentals of interstitial collagen selfassembly. In: Extracellular Mtrix Assembly and Function (Yurchenco, P.D., Birk, D.E. and Mecham, R.P., eds), pp. 15-45. Academic Press, San Diego.

WEISS, P. and FERRIS, W. (1954) Electron-microscopic study of the texture of the basement membrane of larval amphibian skin. Proc. Nat. Acad. Sci. U.S.A., 40: 528-540.
WHITEAR, M. (1970) The skin surface of bony fish. J. Zool., Lond., 160: 437-453.

WHITEAR, M. (1971a) The free nerve endings in fish epidermis. J. Zool., Lond., 163: $231-236$.

WHITEAR, M. (1971b) Cell specialisation and sensory function in fish epidermis. J. Zool., Lond., 163: 237-264.

WHITEAR, M. (1977) A functional comparison between the epidermis of fish and of amphibians. Symp. Zool. Soc. Lond., 39: 291-313.

WHITEAR, M., MITTAL, A.K. and LANE, E.B. (1980) Endothelial layers in fish skin. J. Fish Biol., 17: 43-65.

WHITEAR, M. (1986) The skin of fishes including cyclostomes. Epidermis. Dermis. In: Biology of the Integument. 2. Vertebrates (Bereiter-Hahn, J., Matoltzy, A.G. and Richards, S., eds), pp. 8-64. Springer-Verlag, Heidelberg.

WHITEAR, M. (1990) Causative aspects of microridges on the surface of fish epithelia. J. Submicrosc. Cytol. Pathol., 22: 211-220.

YATA, M., FUJISAWA, S. and YOSHINAKA, R. (2001) Identification and characterization of molecular species of collagen in fish skin. J. Food Sci., 66: 247-251.

ZYLBERBERG, L., BONAVENTURE, J., COHEN-SOLAL, L., HARTMANN, D.J. and BEREITER-HAHN, J. (1992) Organization and characterization of fibrillar collagens in fish scales in situ and in vitro. J. Cell Sci., 103: 273-285. 